Cornell University Law School Scholarship@Cornell Law: A Digital Repository

2011

\title{
Reconsidering Trials in Absentia at the Special Tribunal for Lebanon: An Application of the Tribunal's Early Jurisprudence
}

Maggie Gardner

Cornell Law School, mg2354@cornell.edu

Follow this and additional works at: http://scholarship.law.cornell.edu/facpub

Part of the Criminal Law Commons, Criminal Procedure Commons, and the International Law Commons

\section{Recommended Citation}

Gardner, Maggie, "Reconsidering Trials in Absentia at the Special Tribunal for Lebanon: An Application of the Tribunal's Early Jurisprudence," 43 George Washington International Law Review 91 (2011)

This Article is brought to you for free and open access by the Faculty Scholarship at Scholarship@Cornell Law: A Digital Repository. It has been accepted for inclusion in Cornell Law Faculty Publications by an authorized administrator of Scholarship@Cornell Law: A Digital Repository. For more information, please contact jmp8@cornell.edu. 


\title{
RECONSIDERING TRIALS IN ABSENTIA AT THE SPECIAL TRIBUNAL FOR LEBANON: AN APPLICATION OF THE TRIBUNAL'S EARLY JURISPRUDENCE
}

\author{
MAGgie GARDNER*
}

\begin{abstract}
Since Nuremburg, no individual has been prosecuted in an international or internationalized court entirely in his or her absence. That may soon change. The Special Tribunal for Lebanon, which is empowered to try defendants in absentia, has now confirmed its first indictment. While its trial in absentia procedures were met with concern and criticism from some quarters when they were first announced, reconsideration is warranted in light of subsequent judicial developments. The judges of the Special Tribunal for Lebanon have now established in their preliminary decisions an interpretive approach to the Tribunal's Statute that is adamantly purposive. This purposive approach should lead the judges to apply the Tribunal's groundbreaking trial in absentia provisions in a manner that is consistent with international human rights jurisprudence, thereby quelling most, if not all, of the prior criticism. This Article first clarifies the debate by disentangling different notions of trials in absentia and by outlining the circumstances under which such trials are considered to accord with modern human rights standards. It then re-evaluates the framework for trials in absentia before the Special Tribunal for Lebanon in light of the Tribunal's early jurisprudence, suggesting how the judges should interpret and apply these provisions in keeping with their prior case law. It ends with a more pragmatic evaluation of the costs and benefits of trials in absentia and cautions that such trials, while acceptable under the highest intermational standards of criminal justice, should be undertaken rarely, if at all.
\end{abstract}

\section{INTRODUCTION}

For the first time since the Martin Bormann trial at Nuremburg, there is a distinct possibility that an international criminal trial may be conducted entirely in the defendant's absence. ${ }^{1}$ Unlike all other modern international tribunals, the Special Tribunal for

* Fellow at the Special Tribunal for Lebanon, 2010-2011 academic year, with funding provided by the Human Rights Program of Harvard Law School. J.D. 2007, magna cum laude, Harvard Law School; A.B. 2002, cum laude, Harvard College. The views expressed herein are those of the author and do not necessarily reflect the views of the Special Tribunal for Lebanon. In memory of Judge Antonio Cassese, 1937-2011.

1. See William A. Schabas, In Absentia Proceedings Before International Criminal Courts, in International Criminal. Procedure: Towards a Coherent Body of Law 335, 335-42 
Lebanon (STL or Tribunal) provides for trials in absentia when an accused cannot be brought before the court. ${ }^{2}$ The Tribunal's first indictment was confirmed by the Pre-Trial Judge on June 28, $2011 .^{3}$ Following various preliminary procedures, the Trial Chamber is now actively considering whether to proceed in the absence of the four indicted men. ${ }^{4}$ Its decision on this question can be expected before the end of 2011.5

Many commentators have raised concerns about the STL's trial in absentia regulations, ${ }^{6}$ and more than one individual has concluded that such trials will only delegitimize the Tribunal and harm the overall project of international criminal law. ${ }^{7}$ These concerns must be reconsidered, however, in light of two significant decisions issued by the STL's Appeals Chamber in the last year. ${ }^{8}$ Although these decisions concerned matters unrelated to trials in

(Göran Sluiter \& Sergey Vasiliev eds., 2009) (describing the prosecution of Bormann, including debates over the legitimacy of trials in absentia).

2. See Statute of the Special Tribunal for Lebanon, S.C. Res. 1757, Annex, art. 22, U.N. Doc. S/RES/1757 (May 30, 2007) [hereinafter Statute].

3. See Press Release, Special Tribunal for Leb., Confirmed Indictment Submitted to the Lebanese Authorities (June 30, 2011), http://www.stl-tsl.org/en/media/pressreleases/confirmed-indictment-submitted-to-the-lebanese-authorities.

4. Press Release, Special Tribunal for Leb., Pre-Trial Judge Requests Trial Chamber to Decide on Proceedings in Absentia (Oct. 17, 2011), http://www.stl-tsl.org/en/media/ press-releases/17-10-2011-pre-trial-judge-requests-trial-chamber-to-decide-on-preceedingsin-absentia.

5. See Prosecutor v. Ayyash et al., Case No. STL-11-01, Scheduling Order in Respect of Rule 106 of the Rules of Procedure and Evidence (Oct. 20, 2011) (scheduling a hearing on the question for November 11, 2011).

6. See generally Björn Elberling, The Next Step in History-Writing Through Criminal Law: Exactly How Tailor-Made Is the Special Tribunal for Lebanon?, 21 LEIDEN J. INT'L L. 529 (2008) (discussing inconsistencies between Article 22 of the Statute and Article 6 of the European Convention regarding in absentia proceedings); Paola Gaeta, To Be (Present) or Not To Be (Present): Trials in Absentia Before the Special Tribunal for Lebanon, 5 J. INT'L CRIM. Just. 1165 (2007) (suggesting how Article 22 of the Statute might be harmonized with international human rights standards); Chris Jenks, Notice Otherwise Given: Will in Absentia Trials at the Special Tribunal for Lebanon Violate Human Rights?, 33 FordHAM INT'L L.J. 57 (2009) (concluding that Article 22's in absentia provisions will violate defendants' fair trial rights); Wayne Jordash \& Tim Parker, Trials in Absentia at the Special Tribunal for Lebanon: Incompatibility with International Human Rights Law, 8 J. INT'L CRIM. JusT. 487 (2010) (arguing that Article 22 of the Statute is inconsistent with minimum fair trial standards and that a trial in absentia would undermine the Tribunal's legitimacy); Niccolò Pons, Some Remarks on in Absentia Proceedings before the Special Tribunal for Lebanon in Case of a State's Failure or Refusal to Hand over the Accused, 8 J. INT'L CRIM. JusT. 1307 (2010) (questioning whether the Statute's in absentia provisions can be reconciled in all circumstances with the fundamental right of defendants to be present at trial).

7. See Jordash \& Parker, supra note 6 , at 489 ; Jenks, supra note 6 , at $62-63,100$.

8. See In re Indictment, Case No. STL-11-01/I, Interlocutory Decision on the Applicable Law: Terrorism, Conspiracy, Homicide, Perpetration, Cumulative Charging (Feb. 16, 2011); In re El Sayed, Case No. CH/AC/2010/02, Decision on Appeal of Pre-Trial Judge's Order Regarding Jurisdiction and Standing (Special Tribunal for Leb. Nov. 10, 2010). 
absentia, they provide the framework through which the STL's judges will interpret and apply the Tribunal's Statute and jurisdictional mandate. This Article uses the STL's early jurisprudence to forecast how the judges will interpret the Tribunal's trial in absentia provisions, and it concludes that an approach in keeping with the early STL case law will resolve most, if not all, of the anticipated concerns.

This Article first provides some general background on the STL and the use of trials in absentia in foreign and international courts. It then surveys the process for trials in absentia at the STL and analyzes how the STL judges can be expected to conduct that process in light of the STL's early jurisprudence. Even though this analysis will demonstrate that the problems preliminarily identified by commentators can largely be resolved through application of the Tribunal's early case law, trials in absentia may not further the Tribunal's best interests. The Article thus concludes with a brief discussion of the policy concerns at stake and recommends that the judges apply the Tribunal's trial in absentia provisions restrictively so as to best protect the STL's interests in efficiency and fair justice.

\section{The Special Tribunal for Lebanon}

\section{A. Establishment of the Tribunal}

The STL is mandated to prosecute the "persons responsible for the attack of 14 February 2005 resulting in the death of former Lebanese Prime Minister Rafiq Hariri and in the death or injury of other persons." 9 That attack, caused by an explosion that killed twenty-three people and left a crater ten meters wide and two meters deep in downtown Beirut, ${ }^{10}$ was so devastating for Lebanese society and the stability of the region as a whole that the U.N. Security Council has termed it "a threat to international peace and security."11

In response to the strong domestic and international outcry over the assassination, the U.N. Security Council established in April 2005 the U.N. International Independent Investigation Commission (UNIIIC) to assist the Lebanese authorities in their investigation. ${ }^{12}$ Meanwhile, Lebanon was rocked by a continuing series of

\footnotetext{
9. Statute, supra note 2 , art. 1.

10. Timeline of Events, SPECIAL Tribunal FOR LeB., http://www.stl-tsl.org/en/aboutthe-stl/timeline-of-events (last modified Sept. 15, 2011).

11. Statute, supra note 2 , pmbl.

12. See S.C. Res. 1595, U.N. Doc. S/RES/1595 (Apr. 7, 2005).
} 
attacks, some of them targeting political leaders and prominent journalists, others more indiscriminate yet equally deadly. These subsequent attacks "had consequences similar to those that followed the assassination of Rafiq Hariri, and [their] effects were mutually reinforcing." 13 Over time, the U.N. Security Council expanded UNIIIC's mandate to include seventeen other terrorist acts that occurred both before and after the February 14 attack. ${ }^{14}$

Finally, in December 2005, Lebanon asked the United Nations to establish a tribunal "of an international character" to try those responsible for the February 14 attack. ${ }^{15}$ At the direction of the Security Council, the U.N. Secretary General negotiated and signed an agreement with Lebanon on February 6, 2007, to establish a special tribunal. ${ }^{16}$ Under the agreement and the statute annexed to it, the special tribunal would apply Lebanese criminal law to prosecute those responsible for the February 14 attack, as well as those responsible for other attacks between October 1, 2004 and December 12, 2005, if the Tribunal finds that those attacks "are connected in accordance with the principles of criminal justice and are of a nature and gravity similar to the attack of 14 February 2005." 17

Due to complicated domestic politics, however, the speaker of Lebanon's Parliament refused to convene the Parliament to hold a vote to ratify the agreement with the United Nations. ${ }^{18}$ A majority of the Lebanese Parliament instead requested, via a letter submitted by Lebanon's then-prime minister, that the Security Council move to establish the Tribunal without formal ratification by the

13. Cécile Aptel, Some Innovations in the Statute of the Special Tribunal for Lebanon, $5 \mathrm{~J}$. INT'L CRIM. JUST. 1107, 1109 (2007).

14. See U.N. Secretary-General, Letter dated July 12, 2007 from the Secretary-General addressed to the President of the Security Council, Annex, II 8, U.N. Doc. S/2007/424 (July 12, 2007).

15. See S.C. Res. 1664, pmbl., U.N. Doc. S/RES/1664 (Mar. 29, 2006).

16. This agreement was eventually annexed to U.N. Security Council Resolution 1757. See S.C. Res. 1757, U.N. Doc. S/RES/1757, Annex (May 30, 2007).

17. Statute, supra note 2 , art. 1. The requisite connection with the February 14 attack "includes but is not limited to a combination of the following elements: criminal intent (motive), the purpose behind the attacks, the nature of the victims targeted, the pattern of the attacks (modus operandi) [,] and the perpetrators." Id. Article 1 of the Statute also provides that the United Nations and Lebanon can agree, "with the consent of the Security Council," to extend the temporal mandate of the Tribunal to cover attacks after December 12, 2005. Id.

18. Choucri Sader, A Lebanese Perspective on the Special Tribunal for Lebanon: Hopes and Disillusions, 5 J. INT'L CRIM. Just. 1083, 1083-84 (2007). 
Parliament. ${ }^{19}$ On May 30, 2007, the Security Council acted under Chapter VII of the U.N. Charter to adopt the agreement between Lebanon and the United Nations and to execute the agreement's annex, the statute of the new tribunal. ${ }^{20}$ Although effectively established by the Security Council, the Tribunal is not a subsidiary organ of the United Nations akin to the International Criminal Tribunal for the Former Yugoslavia (ICTY) and the International Criminal Tribunal for Rwanda (ICTR). Rather, because its structure is defined by the agreement originally reached between Lebanon and the United Nations, the STL functions as an autonomous international institution based in The Hague, The Netherlands. ${ }^{21}$

The Tribunal commenced operations on March 1, 2009, immediately following the conclusion of UNIIIC's mandate. ${ }^{22}$ At that point, the Tribunal's prosecutor assumed UNIIIC's investigative work, and the Pre-Trial Judge requested that Lebanon defer its investigation pursuant to Rule 17 of the STL's Rules of Procedure and Evidence (Rules). ${ }^{23}$ Lebanon complied and transferred its relevant investigative and court records to the STL on April 10, 2009. ${ }^{24}$ As a result, the STL gained custody over four persons who had been detained by the Lebanese authorities for more than three years in connection with the case. On April 29, 2009, the STL ordered these persons released after the prosecutor stated that he did not have sufficient credible evidence to support an indictment against any one of them. ${ }^{25}$

19. See U.N. Secretary-General, Letter dated May 15, 2007 from the Secretary General addressed to the President of the Security Council, U.N. Doc. S/2007/281 (May 16, 2007); S.C. Res. 1757 , supra note 16 , pmbl.

20. S.C. Res. 1757, supra note 16, I 1. No country voted against Resolution 1757, but China, Indonesia, Qatar, the Russian Federation, and South Africa abstained from the vote. See U.N. SCOR, 62nd Sess., 5685th mtg., at 5-6, U.N. Doc. S/PV.5685 (May 30, 2007).

21. See About the STL, SPecial Tribunal for Leb., http://www.stl-tsl.org/en/about-thestl (last visited Oct. 4, 2011). The Special Tribunal for Lebanon (STL or Tribunal) retains, however, some connections to the United Nations beyond the circumstances of its creation. For example, the Registrar is a staff member of the United Nations, and the Registrar, Prosecutor, Head of the Defence Office, and judges are all appointed by the U.N. Secretary-General. Statute, supra note 2, arts. 9(3), 11(3), 12(3), \& 13(1).

22. See Timeline of Events, supra note 10.

23. In re El Sayed, Case No. CH/PRES/2010/01, Order Assigning Matter to Pre-Trial Judge, I 3 (Special Tribunal for Leb. Apr. 15, 2010); see also Special Tribunal For Leb., Rules of Procedure and Evidence, r. 17, STL/BD/2009/01/Rev.3/Corr.1 (Nov. 29, 2010), available at http://www.stl-tsl.org/en/documents/rules-of-procedure-and-evidence. I 4.

24. El Sayed, Case No. CH/PRES/2010/01, Order Assigning Matter to Pre-Trial Judge,

25. Id. II $5-6$. 


\section{B. Early Jurisprudence}

A year later, one of those former detainees, Jamil El Sayed, applied to the Tribunal for access to investigative materials related to his detention by the Lebanese authorities. ${ }^{26}$ According to El Sayed, the Lebanese authorities had detained him for three years and eight months without charge on the basis of false evidence. ${ }^{27}$ With access to investigatory material within the Tribunal's possession, he claimed, he could pursue judicial remedies for libel and false statements in a domestic court. ${ }^{28}$

In a preliminary decision, the Pre-Trial Judge determined that the Tribunal had jurisdiction to consider El Sayed's application and that El Sayed had standing before the Tribunal to bring his application. ${ }^{29}$ In its first substantive decision, the Appeals Chamber affirmed these holdings. ${ }^{30}$ As part of its analysis, the Appeals Chamber discussed the Tribunal's inherent power to determine not only the scope of its jurisdiction (compétence de la compétence), but also those "incidental legal issues which arise as a direct consequence of the procedures of which the Tribunal is seized by reason of the matter falling under its primary jurisdiction." ${ }^{1}$ That is, the Tribunal has inherent power to consider legal questions, such as El Sayed's request for documents, arising from the Tribunal's exercise of its primary jurisdiction (in this case, gaining authority over and then releasing the four detainees pursuant to the Rule 17 procedure). This inherent jurisdiction "is rendered necessary by the imperative need to ensure a good and fair administration of justice, including full respect for human rights, as applicable, of all

26. In re El Sayed, Case No. CH/AC/2010/02, Decision on Appeal of Pre-Trial Judge's Order Regarding Jurisdiction and Standing, I 8 (Special Tribunal for Leb. Nov. 10, 2010).

27. Id.

28. Id.

29. See In re El Sayed, Case No. CH/PTJ/2010/005, Order Relating to the Jurisdiction of the Tribunal to Rule on the Application of Mr El Sayed Dated 17 March 2010 and Whether Mr El Sayed Has Standing Before the Tribunal, II 37, 42 (Special Tribunal for Leb. Sept. 17, 2010).

30. See El Sayed, Case No. CH/AC/2010/02, Decision on Appeal of Pre-Trial Judge's Order Regarding Jurisdiction and Standing, at disposition. Although the Appeals Chamber had issued one other decision two days earlier, it dealt with a more technical challenge to an order issued by the Tribunal's president. See In re El Sayed, Case No. CH/AC/2010/ 01, Decision on the Application to Challenge the Order of the President of the Appeals Chamber To Stay the Order of the Pre-Trial Judge and To Call Upon Amicus Curiae (Special Tribunal for Leb. Nov. 8, 2010).

31. See El Sayed, Case No. CH/AC/2010/02, Decision on Appeal of Pre-Trial Judge's Order Regarding Jurisdiction and Standing, II 43, 45. 
those involved in the international proceedings over which the Tribunal has express jurisdiction." ${ }^{2}$

On January 12, 2011, the government of Lebanon collapsed, largely over disagreements about the then-prime minister's support of the STL. ${ }^{33}$ Meanwhile, on January 17, 2011, the STL prosecutor submitted under seal his first indictment to the Pre-Trial Judge, ${ }^{34}$ who then reviewed the indictment and supporting evidence submitted by the prosecutor to determine whether to confirm or dismiss each charge. ${ }^{35}$

Shortly after receiving the indictment, the Pre-Trial Judge submitted to the Appeals Chamber fifteen preliminary questions of law, the answers to which he deemed necessary in order to complete his review of the indictment. ${ }^{36}$ On February 16, 2011, the Appeals Chamber issued its second significant substantive opinion, answering those fifteen questions in a 150-page decision that concluded, among other things, that there is a customary rule of international law regarding the international crime of terrorism; that the third form of joint criminal enterprise (so-called "JCE 3") should not be applied to specific intent crimes like genocide, persecution, and terrorism; and that the prosecutor should only charge crimes cumulatively when each contains an element materially distinct from the other. ${ }^{37}$ Most relevant to the current discussion, however, the Appeals Chamber discussed at length the proper interpretive approach to the Tribunal's Statute and Rules. We return to that interpretive framework below. ${ }^{38}$

32. Id. I 45. Less relevant to the ensuing discussion, the Appeals Chamber also discussed the proper analysis of standing before international courts of limited jurisdiction. See id. I 60 .

33. Anthony Shadid, For Hezbollah, Claiming Victory Could Be Costly, N.Y. TIMEs, Jan. 14, 2011, at A4.

34. The STL prosecutor subsequently amended the indictment, still under seal, on March 11, 2011, and again on May 6, 2011. Press Release, Special Tribunal for Leb., Prosecutor Daniel A. Bellemare Files an Amended Indictment (Mar. 11, 2011), http://www.stltsl.org/en/news-and-press/press-releases/prosecutor-daniel-a-bellemare-files-an-amendedindictment; Press Release, Special Tribunal for Leb., Guidance to the Media Following the Amendment of the Indictment (May 6, 2011).

35. See Rules of Procedure and Evidence, supra note 23, r. 68. The Pre-Trial Judge may also request the prosecutor to submit additional supporting material. Id.

36. See In re Indictment, Case No. STL-11-01/1, Order on Preliminary Questions Addressed to the Judges of the Appeals Chamber Pursuant to Rule 68, Paragraph (G) of the Rules of Procedure and Evidence (Jan. 21, 2011); see also Rules of Procedure and Evidence, supra note 23, r. $68(\mathrm{G})$.

37. See In re Indictment, Case No. STL-1 1-01/I, Interlocutory Decision on the Applicable Law: Terrorism, Conspiracy, Homicide, Perpetration, Cumulative Charging, II 85 , 248-49, 298 (Feb. 16, 2011).

38. See discussion infra Part IV.B. 


\section{Recent Developments}

The Pre-Trial Judge confirmed the indictment on June 28, 2011, but ordered that it should remain confidential for the time being to aid the Lebanese authorities with their efforts to serve the indictment and arrest warrants on the accused. ${ }^{39}$ A redacted version of the indictment was later made public on August 17, 2011.40

The four defendants, all of whom are Lebanese and all of whom are associated with Hezbollah, are charged with conspiring to commit the February 14 attack, with committing or being an accomplice to a terrorist act, with the murder of Rafik Hariri and twentyone others, and with the attempted murder of 231 additional persons. ${ }^{41}$ The Lebanese authorities attempted to serve the indictment and arrest warrants on the four defendants, but those efforts have been unsuccessful. ${ }^{42}$ Although the President of the STL instructed the Lebanese authorities to continue their efforts, he also ordered the indictment to be served through "alternative means," including through advertisement in Lebanese media. ${ }^{43}$ In accordance with Rule 76 bis, advertisements of the indictment were published in major Lebanese newspapers starting September 15, 2011.44 Unfortunately, both the direct and the indirect efforts to serve the defendants have borne no fruit to date, ${ }^{45}$ and on October 17, 2011, the Pre-Trial Judge formally requested that the Trial Chamber decide whether to conduct proceedings in absentia. ${ }^{46}$ The Trial Chamber must now decide whether the requirements of Rule 106 have been met $^{47}$ and whether to proceed with the STL's first trial despite the absence of the accused.

39. Confirmed Indictment Submitted to the Lebanese Authorities, supra note 3.

40. Prosecutor v. Ayyash et al., Case No. STL-11-01/I/PRES, Order Pursuant to Rule 76(E), II 7 (Aug. 18, 2011).

41. See Prosecutor v. Ayyash et al., Case No. STL-11-01/I/PTJ, Indictment (Public Redacted Version), II 1, 4-5, 59 (June 10, 2011). For analysis of the Lebanese law of intentional homicide and attempted homicide, see In re Indictment, Case No. STL-11-01/I, Interlocutory Decision on the Applicable Law: Terrorism, Conspiracy, Homicide, Perpetration, Cumulative Charging, II 149-88.

42. Ayyash, Case No. STL-11-01/I/PRES, Order Pursuant to Rule 76(E), II 8.

43. Id. II 23-24.

44. Prosecutor v. Ayyash et al., Case No. STL-1 1-01/I, Ordonnance de Saisine de la Chambre de Première Instance Conformément à l'Article 105 bis, Paragraphe A) du Règlement de Procédure et de Preuvre aux Fins de Statuer sur l'Engagement d'une Procédure par Défaut, I 15 (Oct. 17, 2011).

45. Id. \ 16 .

46. Id. at disposition.

47. For discussion of the Rule 106 requirements, see infra, Part IV.A. 
III. In Absentia Trlals under International LaW

\section{A. Contrast with U.S. Tradition}

Depending on one's legal background, the term "trial in absentia" can refer to many types of situations in which a trial is conducted in the absence of the defendant: when a defendant has been present for part of a trial but then absconds; when a defendant is removed from the courtroom for disruptive behavior; when during a lengthy trial a defendant falls ill; or when a defendant, although in custody, refuses to continue attending the trial. This Article, however, uses the term as it is often used in civil law jurisdictions: to describe only those situations where the accused is never brought before a court, even for arraignment, and is tried entirely in his or her absence. Indeed, Rule 104 effectively defines proceedings in absentia to exclude instances in which the accused has made any "appearance"-even if only by video-link or through designated counsel-before the Tribunal. ${ }^{48}$ So defined, trials in absentia are not allowed in U.S. courts, though U.S. courts do allow trials to continue in the absence of the accused. ${ }^{49}$ Other countries allow full trials in absentia, and the legitimacy of such trials has been affirmed-within certain limits-by international human rights bodies. ${ }^{50}$

This difference among judicial systems regarding the use of trials in absentia is not necessarily a rights-based one. The right of a criminal defendant to attend his own trial in order to defend himself fully is universally recognized as a fundamental right, enshrined in the International Covenant on Civil and Political Rights (ICCPR) ${ }^{51}$ and in the U.S. Constitution through the Confrontation Clause of the Sixth Amendment and the Due Process Clauses of the Fifth

48. Rule 104 provides in full:

Once an accused has appeared before the Tribunal in person, by video-conference, or by Counsel appointed or accepted by him, without having expressly and in writing waived his right to be present at proceedings before the Tribunal, the proceedings shall not be deemed to be in absentia pursuant to Article 22 of the Statute.

Rules of Procedure and Evidence, supra note 23, r. 104.

49. See Crosby v. United States, 506 U.S. 255, 262 (1993).

50. See, e.g., Sejdovic v. Italy, 2006-Il Eur. Ct. H.R. 241; U.N. Human Rights Comm., General Comment No. 32, 90th Sess., July 7-29, 2007, U.N. Doc. CCPR/C/GC/32, I 36 (Aug. 23, 2007).

51. International Covenant on Civil and Political Rights art. 14(3) (d), Dec. 16, 1966, 999 U.N.T.S. 171 [hereinafter ICCPR] ("In the determination of any criminal charge against him, everyone shall be entitled to the following minimum guarantees, in full equality: ... (d) To be tried in his presence, and to defend himself in person or through legal assistance of his own $[c]$ hoosing ...."). 
and Fourteenth Amendments. ${ }^{52}$ As a personal right of the defendant, however, the right to attend one's criminal trial can be waived, and such waiver can be inferred by the defendant's absence at trial if he had notice of the ongoing criminal proceedings but chose not to attend. ${ }^{53}$

The right of a defendant to attend his trial should not, however, be confused with his duty to attend trial, a duty that enables the court to fulfill its truth-seeking purpose. The U.S. Supreme Court speaks of "the notion that a fair trial could take place only if the jurors met the defendant face-to-face and only if those testifying against the defendant did so in his presence" 54 ; the European Court of Human Rights (ECtHR) has likewise emphasized that "it is of capital importance that a defendant should appear, both because of his right to a hearing and because of the need to verify the accuracy of his statements and compare them with those of the victim-whose interests need to be protected-and of the witnesses."55

Besides protecting the truth-seeking function of trials, states also enforce the duty to attend in order to prevent the obstruction of justice, as delay caused by the defendant's absence can result in the dispersal of evidence, the expiration of statutes of limitation, or simply the miscarriage of justice due to paralyzed proceedings. ${ }^{56}$ Delayed criminal proceedings are of particular concern in civil law systems, where criminal trials are not so much a contest between two parties, but a broader societal effort to restore public order. ${ }^{57}$ These societal interests in truth-seeking and preventing the obstruction of justice are often, however, in tension: the truth-seeking function is best fulfilled through the defendant's presence, but preventing the obstruction of justice may require continuing in the

52. United States v. Gagnon, 470 U.S. 522, 526 (1985) (per curiam).

53. See, e.g., Taylor v. United States, 414 U.S. 17, 19-20 (1973) (per curiam); Sejdovic, 2006-II Eur. Ct. H.R. II 86-87; Prosecutor v. Jean-Bosco Barayagwiza, Case No. ICTR-9719-T, Decision on Defence Counsel Motion to Withdraw, I 6 (Nov. 2, 2000); General Comment No. 32, supra note 50 , I 36.

54. Crosby, 506 U.S. at 259.

55. Krombach v. France, 2001-II Eur. Ct. H.R. 37, 61.

56. See Colozza v. Italy, 89 Eur. Ct. H.R. (ser. A) at 15 (1985).

57. Ralph Riachy, Trials in Absentia in the Lebanese Judicial System and at the Special Tribunal for Lebanon: Challenge or Evolution?, 8 J. INT'L CRIM. JUST. 1295, 1297 (2010). Judge Riachy is currently the vice president of the STL and is a member of the Tribunal's Appeals Chamber. Appeals Chamber, SPECIAL Tribunal FOR LeB., https://www.stl-tsl.org/en/aboutthe-stl/structure-of-the-stl/chambers/appeals-chamber (last visited Oct. 6, 2011); Vice President-judge Ralph Riachy, SPECIAL TRIBUNAl, FOR LeB., https://www.stl-tsl.org/en/about-thestl/key-characters/judges-of-the-special-tribunal-for-lebanon/vice-president-judge-ralphriachi (last visited Oct. 6, 2011). 
defendant's absence so that the defendant cannot, in effect, veto his own trial.

Thus while a criminal defendant may waive his right to attend his trial, legislatures and courts may nevertheless sanction his abdication of the duty to attend his trial. U.S. courts, for example, have developed the doctrine of "fugitive disenfranchisement," which allows courts to reject a defendant's appeal out of hand if the defendant has absconded during the pendency of the appeal and has not yet been recaptured. ${ }^{58}$ The doctrine is justified in part by the need to deter flight and to sanction the obstruction of justice, ${ }^{59}$ though the Supreme Court has carefully limited its application to ensure the sanction's reasonable connection and proportionality to the defendant's wrongdoing. ${ }^{60}$ All the same, U.S. federal courts traditionally will not try an absent defendant unless the trial is fully underway at the time he absconds. ${ }^{61}$ This is not necessarily a constitutional rule 62 ; indeed, individual states have drawn an earlier line at which trials in absentia may commence, at a point between arraignment and the start of trial. ${ }^{63}$

58. See Ortega-Rodriguez v. United States, 507 U.S. 234, 239 (1993).

59. See id. at 240-42 (noting the additional justification for fugitive disenfranchisement of ensuring the enforceability of the court's judgment).

60. See Degen v. United States, 517 U.S. 820, 828 (1996) (preventing an absent criminal defendant from defending his property in a related civil forfeiture suit "is too blunt an instrument for advancing" the interests that justify the fugitive disenfranchisement doctrine); Ortega-Rodriguez, 507 U.S. at 249 (noting that federal courts should not automatically dismiss appeals from former fugitives who file their appeals after their return to custody).

61. See FED. R. CRIM. P. 43; see also Crosby v. United States, 506 U.S. 255, 259-60 (1993) (emphasizing importance of the defendant's presence in order to achieve a fair trial, but noting also the need to allow trial to continue in the defendant's absence so that the defendant may not unilaterally defeat the proceedings against him).

62. Crosby, 506 U.S. at 262 (basing decision solely on tradition and the text of Federal Rule of Criminal Procedure 43 and declining to consider constitutional arguments).

63. See, e.g., State v. Luna, 936 A.2d 957, 962, 964-65 (N.J. 2007) (distinguishing Crosby as based on Federal Rule of Criminal Procedure 43 and reaffirming state law precedent that a criminal defendant can be tried in absentia if he absconds before trial); Commonwealth v. Johnson, 734 A.2d 864, 868 (Pa. Super. Ct. 1999) (same). The U.S. Supreme Court has noted that "[i]f a clear line is to be drawn marking the point at which the costs of delay are likely to outweigh the interests of the defendant and society in having the defendant present, the commencement of trial is at least a plausible place at which to draw that line"-leaving open the legitimacy of other courts choosing to draw the line at earlier stages of the proceedings. Crosby, 506 U.S. at 261. U.S. courts do not draw the line even earlier, before arrest and arraignment, perhaps on account of common law tradition, such as the importance in an adversarial model of both parties being present, see, e.g., ANTONIO Cassese, International Criminal Law 392-93 (2d ed. 2008), or the old principle that "[ $t]$ he whole theory of criminal proceedings is based upon the idea of the defendant being in the power, and under the control of the court, in his person," People v. Genet, 59 N.Y. 
Some countries have instead viewed full trials in absentia, as the term is used in this Article, as a legitimate sanction for deterring flight. Procès par contumace, used in some civil law countries, allows for trials in absentia and restricts the absent defendant's rights as a sanction for his flight; for example, he may be denied legal representation and, if convicted, may forfeit his civil rights. ${ }^{64}$ Over the last twenty-five years, however, the ECtHR has shifted the framework of trials in absentia in European jurisdictions away from such a sanctions-based paradigm and towards a rights-based approach. ${ }^{65}$ As a result, procès par contumace has been replaced with procès par defaut, in which the rights of defendants are not punitively curtailed. ${ }^{66}$ Thus, while the ECtHR has recognized that states may conduct trials in absentia to prevent absent defendants from obstructing the judicial process, it has also indicated any curtailment of the defendant's rights must be proportional and not violate fundamental rights. ${ }^{67}$

In sum, both the right and obligation of a defendant to attend his trial is universally recognized. For reasons of tradition and differences in the weighing of societal values, some states allow trials in absentia even if the defendant has never been brought before the court. Such trials in absentia are acceptable under international law, but with important limitations, to which we now turn.

\section{B. International Jurisprudence}

The U.N. Human Rights Committee, the independent body of experts that monitors compliance with the ICCPR, has emphasized that the ICCPR explicitly protects a defendant's right “ $[\mathrm{t}] \mathrm{o}$ be tried in his presence." 68 It has also repeatedly noted, however, that "[t]his provision and other requirements of due process enshrined

80,81 (1874); $c f$. McDonald v. Mabee, 243 U.S. 90, 91 (1917) ("The foundation of jurisdiction is physical power ....").

64. See Annual Report 2009-2010, Special Tribunal for Leb., Il 41 [hereinafter First Annual Report], http://www.stl-tsl.org/en/documents/president-s-reports-and-memoranda/annual-report-2009-2010 (last visited Oct. 7, 2011).

65. France, for example, amended its code of criminal procedure in 2004 to end its use of procès par contumace, following repeated criticisms by the European Court of Human Rights (ECtHR). See Pons, supra note 6, at 1309 n.8.

66. See First Annual Report, supra note 64, I 41.

67. See, e.g., Sejdovic v. Italy, 2006-II Eur. Ct. H.R. 241, If 92 ("The legislature must accordingly be able to discourage unjustified absences, provided that any sanctions used are not disproportionate in the circumstances of the case and the defendant is not deprived of his right to be defended by counsel.").

68. U.N. Human Rights Comm., Mbenge v. Zaire, I 14.1, U.N. Doc. CCPR/C/OP/2 (Mar. 25, 1983). 
in article 14 cannot be construed as invariably rendering proceedings in absentia inadmissible," particularly when the accused person "declines to exercise his right to be present." 69 Countries may utilize trials in absentia, but only if they first provide defendants with adequate and timely notice of the date and place of their trial and request their attendance. ${ }^{70}$ So far, the U.N. Human Rights Committee has only considered situations where prosecuting authorities did not take all reasonable steps to notify the defendant, ${ }^{71}$ leaving unanswered whether any other requirements must also be met before a trial in absentia is compliant with the strictures of Article 14.

Of the regional human rights bodies, only the ECtHR has expanded upon the U.N. Human Rights Committee's reasoning and more fully addressed the legitimate bounds of in absentia proceedings. Article 6 of the European Convention closely follows Article 14 of the ICCPR, but it does not explicitly include the right to be tried in one's presence. ${ }^{72}$ Nonetheless, the ECtHR has concluded that this right can be inferred from the other provisions of Article 6.73 The ECtHR recognizes that an individual can waive his right to be present, whether explicitly or implicitly, but that waiver must be informed voluntary, and unequivocal. ${ }^{74}$ Thus, an accused individual's absence on the date of trial can be interpreted as an implied waiver of the right to be present, but only if the accused has received notice of the charges and the date of trial, indicating that the inferred waiver is informed, and if the accused is not prevented from attending for reasons beyond his control, demonstrating that the inferred waiver is voluntary. ${ }^{75}$ If an individual is convicted in his absence but later claims he did not receive notice or was prevented from attending due to circumstances beyond his control, the court must hear his challenge. ${ }^{76}$ If the court deter-

69. Id.

70. General Comment No. 32, supra note 50, I 36; U.N. Human Rights Comm., Maleki v. Italy, II 9.3, U.N. Doc. CCPR/C/66/D/669/1996 (July 27, 1999).

71. See, e.g., U.N. Human Rights Comm., Osiyuk v. Belarus, I 8.3, U.N. Doc. CCPR/ C/96/D/1311/2004 (Aug. 21, 2009); U.N. Human Rights Comm., Salikh v. Uzbekistan, II 9.5, U.N. Doc. CCPR/C/95/D/1382/2005 (Apr. 22, 2009).

72. See Convention for the Protection of Human Rights and Fundamental Freedoms art. 6(3), Nov. 4, 1950, E.T.S. No. 5.

73. Sejdovic v. Italy, 2006-II Eur. Ct. H.R. 241, I 81; T v. Italy, 245 Eur. Ct. H.R. (ser. A) at 41 (1992).

74. See, e.g., Sejdovic, 2006-II Eur. Ct. H.R., II 86-87.

75. See F.C.B. v. Italy, 208 Eur. Ct. H.R. (ser. A) at 21 (1991); Colozza v. Italy, 89 Eur. Ct. H.R. (ser. A) at 14 (1985); see also Sejdovic, 2006-II Eur. Ct. H.R., II 100-01.

76. See Somogyi v. Italy, 2004-IV Eur. Ct. H.R. 105, I 72. 
mines there was a violation of the defendant's rights (e.g., he did not receive adequate notice), the violation should be remedied by a retrial. ${ }^{77} \mathrm{~A}$ full retrial before a court of first instance is not, however, necessarily required: the ECtHR has noted that an appeal hearing that allows the submission of new evidence and permits de novo factual and legal determinations could satisfy this requirement. ${ }^{78}$

Although the ICCPR and the European Convention have deemed trials in absentia to be in accordance with fair trial rights, international criminal courts have by and large avoided resorting to them. As Professor Schabas has described in some detail, ${ }^{79}$ the International Military Tribunal at Nuremburg (IMT), which did have the power to try defendants in absentia, only did so once, in the case of Martin Bormann. Meanwhile, the IMT refused to continue the trial of Gustav Krupp Von Bohlen after he became too senile to attend and follow the proceedings. While this decision was based primarily on the inability of Krupp to understand the charges against him and to participate in his defense, the court concluded that proceeding with trial would not be just when "nature rather than flight or contumacy" prevented Krupp's full attendance. 80

Since Nuremburg, the statutes of the modern international criminal tribunals have not allowed for trials in absentia, ${ }^{81}$ perhaps on the theory that the cases are so complicated and sensitive, it would be "extremely difficult or even impossible" for the tribunals to fulfill their truth-seeking functions in the absence of the accused. ${ }^{82}$

77. See, e.g., Sejdovic, 2006-II Eur. Ct. H.R., II 82 (“[A] denial of justice . . . undoubtedly occurs where a person convicted in absentia is unable subsequently to obtain from a court which has heard him a fresh determination of the merits of the charge, in respect of both law and fact, where it has not been established that he has waived his right to appear and defend himself."); Somogyi, 2004-IV Eur. Ct. H.R., I 66.

78. See Sejdovic, 2006-II Eur. Ct. H.R., Il 85; Jones v. United Kingdom, App. No. 30900/ 02, 37 Eur. H.R. Rep. 269, 278 (2003).

79. See Schabas, supra note 1 , at 336-53.

80. See $i d$. at $342-50$.

81. See id. at 335; Jordash \& Parker, supra note 6, at 488. While the International Criminal Court (ICC) allows charges to be confirmed in the absence of the defendant, it nonetheless requires defendants to be present for at least part of their trials. See Schabas, supra note 1 , at $368,374-75$.

82. Prosecutor v. Blaškic, Case No. IT-95-14, Judgment on the Request of the Republic of Croatia for Review of the Decision of Trial Chamber II of 18 July 1997, II 59 (Int'l Crim. Tribunal for the Former Yugoslavia Oct. 29, 1997). In his report on the drafting of the International Criminal Tribunal for the Former Yugoslavia (ICTY) Statute, the U.N. Secretary General commented that " $[\mathrm{t}]$ here is a widespread perception that trials in absentia should not be provided for in the statute, as this would not be consistent with article 14 [of the ICCPR], which provides that the accused shall be entitled to be tried in his presence." 
The tribunals have, however, allowed trials to continue when the defendant refuses to attend further proceedings, recognizing that any other outcome would allow the accused "to impede the administration of justice" and would be "tantamount to judicial abdication of the principle of legality and a capitulation to a frustration of the ends of justice without justification." 83 That is, the ad hoc tribunals have recognized, like the U.S. Supreme Court and the ECtHR, that at some point the benefit of the defendant's presence for the truth-seeking process is outweighed by the importance of preventing the defendant from obstructing his trial. If the defendant has waived, explicitly or implicitly, his right to attend his trial, justice may require proceeding without him.

\section{The Framework for Trials In Absentla at the Special Tribunal for Lebanon}

\section{A. Statutory Framework}

Article 22 of the STL Statute (Statute) sets the STL apart from its immediate predecessors by allowing trials in absentia from the outset. Article 22 provides as follows:

1. The Special Tribunal shall conduct trial proceedings in the absence of the accused, if he or she:

(a) Has expressly and in writing waived his or her right to be present;

(b) Has not been handed over to the Tribunal by the State authorities concerned;

(c) Has absconded or otherwise cannot be found and all reasonable steps have been taken to secure his or her appearance before the Tribunal and to inform him or her of the charges confirmed by the Pre-Trial Judge.

2. When hearings are conducted in the absence of the accused, the Special Tribunal shall ensure that:

(a) The accused has been notified, or served with the indictment, or notice has otherwise been given of the indictment through publication in the media or communication to the State of residence or nationality;

(b) The accused has designated a defence counsel of his or her own choosing, to be remunerated either by the accused or, if the accused is proved to be indigent, by the Tribunal;

U.N. Secretary-General, Report of the Secretary General Pursuant to Paragraph 2 of Security Council Resolution 808 (1993), II 101, U.N. Doc. S/25704 (May 3, 1993).

83. Prosecutor v. Sesay, Case No. SCSL-04-15-T, Ruling on the Issue of the Refusal of the Third Accused, Augustine Gbao, To Attend Hearing of the Special Court for Sierra Leone on 7 July 2004 and Succeeding Days, If 8 (July 12, 2004); see also Prosecutor v. JeanBosco Barayagwiza, Case No. ICTR-97-19-T, Decision on Defence Counsel Motion to Withdraw, I 24 (Nov. 2, 2000). 
(c) Whenever the accused refuses or fails to appoint a defence counsel, such counsel has been assigned by the Defence Office of the Tribunal with a view to ensuring full representation of the interests and rights of the accused.

3 . In case of conviction in absentia, the accused, if he or she had not designated a defence counsel of his or her choosing, shall have the right to be retried in his or her presence before the Special Tribunal, unless he or she accepts the judgment.

The STL judges have outlined through the Rules how Article 22 should be implemented. Rule 105 bis provides a timeline for the Pre-Trial Judge to request the Trial Chamber initiate proceedings in absentia by determining that the requirements of Rule 106, which are nearly identical to those of Article 22, have been met. ${ }^{84}$ The Pre-Trial Judge invoked Rule 105bis on October 17, 2011, in asking the Trial Chamber to make a Rule 106 determination for the Ayyash case. ${ }^{85}$ Rule 106 provides that:

Where the accused:

(i) has expressly and in writing waived his right to be present at proceedings before the Tribunal;

(ii) has not been handed over to the Tribunal by the State authorities concerned within a reasonable time; or

(iii) has absconded or otherwise cannot be found and all reasonable steps have been taken to secure his appearance before the Tribunal and to inform him of the charges by the Pre-Trial Judge; 86

the Trial Chamber shall conduct proceedings in absentia.

(B) Where the accused is not present on account of the failure or refusal of the relevant State to hand him over, before deciding to conduct proceedings in absentia, the Trial Chamber shall:

(i) consult with the President and ensure that all necessary steps have been taken with a view to ensuring that the accused may, in the most appropriate way, participate in the proceedings; and

(ii) ensure that the requirements of Article 22(2) of the Statute have been met.

Rules 108 and 109 spell out the ramifications, in light of Article 22(3), if an accused person appears before the Tribunal during the

84. Rules of Procedure and Evidence, supra note 23, r. 105bis.

85. See Prosecutor v. Ayyash et al., Case No. STL-1 1-01/1, Ordonnance de Saisine de la Chambre de Première Instance Conformément à l'Article 105 bis, Paragraphe A) du Règlement de Procédure et de Preuvre aux Fins de Statuer sur l'Engagement d'une Procédure par Défaut, disposition (Oct. 17, 2011).

86. The English version of Rule 106(A) (iii) appears to contain a minor error: the language of Article 22(1)(c), from which Rule 106(A) (iii) is copied, refers to "the charges confirmed by the Pre-Trial Judge," Statute, supra note 2, art. 22(1)(c), as does the French version of Rule 106(A) (iii) ("des charges confirmées par le Judge de la mise en état"). Special Tribunal for Leb., Règlement de Procédure et de Preuve, r. 17, STL/BD/2009/01/Rev.3/Corr.1 (Nov. 29, 2010), available at http://www.stl-tsl.org/images/RPE/RPE_FR_November_2010 _Modified.pdf. 
course of his trial in absentia; after the trial judgment or sentence has been issued in his absence; or during or after an appeal taken by the prosecution. ${ }^{87}$

Why did the drafters of the STL Statute adopt such a different approach from the other international and hybrid tribunals? The answer likely lies in the STL's structure and mandate, namely (i) the need to account for the practices of the Lebanese criminal system, and (ii) the likelihood that the alleged perpetrators of the terrorist crimes falling under the STL's jurisdiction may never be arrested or brought to trial in any other manner.

Unlike the other ad hoc tribunals and the International Criminal Court (ICC), the STL is structured to apply only Lebanese law, as opposed to international law, to the substantive crimes within its jurisdiction. ${ }^{88}$ Its Rules are also to be guided, where appropriate, by the Lebanese Code of Criminal Procedure. ${ }^{89}$ Given this focus on Lebanese law, coupled with allowance under Lebanese law of trials in absentia both for misdemeanors and for felonies, ${ }^{90}$ the inclusion of trials in absentia before the STL is perhaps not surprising. ${ }^{91}$

Also unlike the other ad hoc tribunals, though similarly to many cases before the ICC, the STL is operating in the context of an unresolved political crisis. Indeed, within Lebanon and throughout the region, the STL is the subject of great controversy. Hezbollah, a political and military organization that effectively controls portions of Lebanon and is part of the country's current governing coalition-and with which all four of the accused are affiliatedhas denounced the STL and refused to cooperate with it. ${ }^{92}$ It is thus not hard to foresee a situation where one or more defendants

87. Rules of Procedure and Evidence, supra note 23, rs. 108-09.

88. Statute, supra note 2, art. 2; In re Indictment, Case No. STL-11-01/I, Interlocutory Decision on the Applicable Law: Terrorism, Conspiracy, Homicide, Perpetration, Cumulative Charging, I 44 (Feb. 16, 2011).

89. Statute, supra note 2, art. 28(2); Rules of Procedure and Evidence, supra note 23, r. 3.

90. Act No. 328 of 7 Aug. 2001 (New Code of Criminal Procedure), arts. 165-67, 171-74, 282-94 (Leb.), available at http://www.stl-tsl.org/en/documents/relevant-law-andcase-law/applicable-law; see also Riachy, supra note 57, at 1296, 1299-1300 (describing regulation of trials in absentia under Lebanese law); Pons, supra note 6, at 1307-09 (same).

91. See Aptel, supra note 13, at 1121 (asserting that Article 22 was adopted at the insistence of the Lebanese drafters based on the use of trials in absentia in Lebanese courts).

92. See Prosecutor v. Ayyash et al., Case No. STL-11-01/I/PTJ, Indictment (Public Redacted Version), I 59 (June 10, 2011); Borzou Daraghi, Hariri Slaying Inquiry Says Calls Pointed to Hezbollah, L.A. Times (Aug. 17, 2011), http://articles.latimes.com/2011/aug/17/ world/la-fg-lebanon-tribunal-20110818; Anthony Shadid, Hezbollah Chooses Lebanon's Next Prime Minister, N.Y. TImes (Jan. 25, 2011), http://www.nytimes.com/2011/01/25/world/ middleeast/25lebanon.html?pagewanted=all. 
will refuse to surrender to the Tribunal and no authority will be able or willing to detain and transfer them to The Hague.

The ICTY and ICTR faced a similar problem when uncooperative or barely cooperative states were unwilling to hand over indicted leaders. It took sixteen years from the date of the indictment for the ICTY to obtain custody of Ratko Mladic. ${ }^{93}$ With the possibility of full trials in absentia implicitly barred by the ICTY statute, the judges of the ICTY instead adopted a procedure, embodied in Rule 61 of the ICTY's Rules of Procedure and Evidence, that effectively allowed them to reconfirm the indictment through a public hearing. ${ }^{94}$ Rule 61 allows the prosecutor to present evidence and witnesses before the court despite the absence of the defendant, and it calls on the judges to determine whether "there are reasonable grounds for believing that the accused has committed all or any of the crimes charged in the indictment."95 Primarily a tool for preserving evidence and publicly shaming those indicted, as well as the countries that refuse to turn them over, Rule 61 proceedings fell into disuse once the Tribunal gained custody of a significant number of defendants. ${ }^{96}$

The ICTR never made use of its equivalent provision, ${ }^{97}$ but after seventeen years, nine indictees have still not been arrested and turned over to the court. ${ }^{98}$ In May 2009, its judges amended the ICTR's Rules of Procedure and Evidence to allow the taking of evidence in cases where the indictee has remained stubbornly at large. ${ }^{99}$ The new Rule 71 bis allows the court to hear witness testimony in such cases, thereby preserving evidence for possible

93. Press Release, Int'l Crim. Tribunal for the Former Yugoslavia, Tribunal Welcomes the Arrest of Ratko Mladic (May 26, 2011), http://www.icty.org/sid/10671.

94. See generally Schabas, supra note 1, at 360-61 (describing Rule 61 proceedings and how they resemble and fulfill some of the purposes of trials in absentia); Hakan Friman, Rule 61 Proceedings (ICTY, ICTR), in The Oxford CoMpanion to InTERnational Criminal JuSTICE 494-95 (Antonio Cassese ed., 2009) (explaining the purpose, procedures, and consequences of Rule 61 proceedings and tracing the use of such proceedings by the ICTY).

95. International Tribunal for the Prosecution of Persons Responsible for Serious Violations of International Humanitarian Law Committed in the Territory of the former Yugoslavia since 1991, Rules of Procedure and Evidence, r. 61(C), U.N. Doc. IT/32/Rev. 45 (Dec. 8, 2010).

96. See Schabas, supra note 1, at 361; Friman, supra note 94, at 495.

97. Friman, supra note 94, at 495. For the equivalent provision, see International Criminal Tribunal for Rwanda, Rules of Procedure and Evidence, r. 61, U.N. Doc. ITR/3/Rev. 19 (Oct. 1, 2009) [hereinafter ICTR Rules of Procedure and Evidence].

98. See Status of Cases, INT'L CRIM. Tribunal. for Rwanda, http://www.unictr.org/ Cases/tabid/204/Default.aspx (last visited Oct. 9, 2011).

99. See Prosecutor v. Kabuga, Case No. ICTR-98-44B-R71 bis, Decision on the Prosecutor's Request for Preservation of Evidence by Special Deposition for a Future Trial (Pursuant to Rule 71 bis), II 3-5 (Mar. 15, 2011). 
admission at a later trial, if (i) "reasonable efforts have been made to execute the arrest warrant," (ii) further efforts to execute the warrant are not likely to be successful "within a reasonable time," and (iii) proceeding with special depositions would be "in the interests of justice." 100 Rule 71 bis, although not a trial procedure, nevertheless shares some similarities with Article 22 of the STL Statute, ${ }^{101}$ including the same motivating principle: "to prevent fugitive accused from avoiding effective prosecution and obstructing the proper administration of justice." 102

Both the ICTY and ICTR have thus struggled with how to prevent the obstruction of justice despite the unwillingness of states to arrest and transfer those indicted. With broader temporal and subject-matter jurisdiction, however, the ICTY and ICTR could at least occupy their attention with other cases while waiting for the capture of high-profile fugitives. The STL in contrast may have only one case; the luxury of time is not on its side. All of these considerations-the practical difficulties faced by the other ad hoc courts, the limited jurisdiction of the STL, opposition to the Tribunal's project in Lebanon and the region, and the use of trials in absentia in Lebanese procedure-were likely factors in the decision to dust off and redeploy the procedural tool of trials in absentia in the context of internationalized criminal justice. ${ }^{103}$ Because of the novelty of this procedural tool in modern international criminal law, however, its potential application by the STL has understandably raised questions and quite a number of criticisms. Luckily, there is a growing indication that the STL will answer these questions in a manner that should resolve most, if not all, concerns.

\section{B. Interpretive Framework}

The STL Appeals Chamber's first decision under Rule 176bis (Rule 176bis Decision) has drawn attention mostly for its conclusion that an international crime of terrorism exists as a matter of

100. ICTR Rules of Procedure and Evidence, supra note 97, r. 71 bis (E).

101. For example, International Criminal Tribunal for Rwanda (ICTR) Rule 71 bis entails a showing that reasonable steps have been taken to execute the arrest warrant; mandates the appointment of counsel to represent the absent defendant during the Rule 71 bis proceedings; and, based on the Trial Chamber's early application of the Rule, may consider a finding that the defendant is aware of the outstanding warrant and is purposefully evading arrest. Id. r. 71 is (C), (G) (ii); Kabuga, Case No. ICTR-98-44B-R71 bis, II 12.

102. Kabuga, Case No. ICTR-98-44B-R71bis, II 15.

103. As the president of the STL has described, the rationale for Article 22 is that "international justice must not be thwarted, either by the will of the accused to evade justice, or by the intent of a State to shelter such an accused by refusing to hand him over to the international tribunal." First Annual Report, supra note 64, II 37. 
customary international law. ${ }^{104}$ Another portion of the decision has thus far been largely overlooked, even though it will have a much broader impact on the work of the STL. At the outset of the Rule 176bis Decision, the Appeals Chamber elucidated a general interpretive framework for the Statute that will shape the future jurisprudence of the Tribunal; in particular, it will guide the interpretation of Article 22 and, by extension, the related Rules regarding proceedings in absentia.

As a starting point, the Appeals Chamber held that the Statute should be interpreted according to Article 31 of the Vienna Convention on the Law of Treaties (VCLT), namely "in good faith in accordance with the ordinary meaning to be given to the terms of the treaty in their context and in the light of its object and purpose." 105 The Appeals Chamber reserved the question of whether the STL Statute should be interpreted as a treaty (i.e., between Lebanon and the United Nations) or as a U.N. Security Council resolution (i.e., as part of Resolution 1757). Nonetheless, it noted the remarks of the International Court of Justice (ICJ) in its recent Advisory Opinion on the legality of Kosovo's declaration of independence ${ }^{106}$ that U.N. Security Council resolutions should be interpreted not only in accordance with the VCLT, but also in light of "statements by representatives of members of the Security Council made at the time of [the resolution's] adoption, other resolutions of the Security Council on the same issue, as well as the subsequent practice of relevant United Nations organs and of

104. See, e.g., Stefan Kirsch \& Anna Oehmichen, Judges Gone Astray: The Fabrication of Terrorism as an International Crime by the Special Tribunal for Lebanon, 1 DURHAM L. REv. ONLINE 1, 3 (2011), http://durhamlawreview.co.uk/files/Kirsh_house_style_1.pdf; Ben Saul, Legislating from a Radical Hague: The United Nations Special Tribunal for Lebanon Invents an International Crime of Transnational Terrorism, 24 LEIDEN J. INT'L L. 677, 677 (2011); Michael P. Scharf, Special Tribunal for Lebanon Issues Landmark Ruling on Definition of Terrorism and Modes of Participation, AM. Soc'Y INT'L L. INSIGHTS (Mar. 4, 2011), http://www.asil. org/pdfs/insights/insight110304.pdf; see also In re Indictment, Case No. STL-11-01/I, Interlocutory Decision on the Applicable Law: Terrorism, Conspiracy, Homicide, Perpetration, Cumulative Charging, I 85 (Feb. 16, 2011) (concluding that a number of treaties, U.N. resolutions, and legislative and judicial materials indicate the existence of an international crime of terrorism).

105. In re Indictment, Case No. STL-11-01/1, Interlocutory Decision on the Applicable Law: Terrorism, Conspiracy, Homicide, Perpetration, Cumulative Charging, II 26, 28 (quoting the Vienna Convention on the Law of Treaties, art. 31(1), May 23, 1969, 1155 U.N.T.S. 331).

106. Accordance with International Law of the Unilateral Declaration of Independence in Respect of Kosovo, Advisory Opinion (July 22, 2010) [hereinafter Kosovo Advisory Opinion], available at http://www.icj-cij.org/docket/files/141/15987.pdf. 
States affected by those given resolutions."107 In identifying the STL Statute's object and purpose, the Appeals Chamber therefore took into account not only the text of the Statute as a whole, but also related U.N. Security Council resolutions, the Report of the U.N. Secretary-General on the Tribunal's Establishment, ${ }^{108}$ and the statements of Security Council members upon adoption of the Statute. ${ }^{109}$ The Appeals Chamber concluded that the overarching object and purpose of the STL Statute, as these sources uniformly demonstrated, is the administration of justice in a fair and efficient manner, including the application of the highest international standards of criminal justice. ${ }^{110}$

In discussing Article 31 of the VCLT, the Appeals Chamber emphasized a contextual and teleological approach to interpretation. It rejected an interpretive approach that focuses first on the "ordinary meaning" of words to the exclusion of other considerations: even the determination that a text is "clear" requires an act of interpretation, which incorporates-consciously or not-the contextual understanding and perspective of the interpreter. ${ }^{111}$ Thus, the Appeals Chamber wrote, "[o]ne must always start with a statute's language. But that must be read within the statute's legal and factual contexts." 112

From this general framework emerges a strong indication that the STL judges will interpret Article 22 of the Statute and the related Rules on trials in absentia in conformity with the ICCPR and the ECtHR's jurisprudence, even if the provisions are also susceptible to other interpretations. First, these two bodies of law represent the highest international standards of criminal justice visà-vis trials in absentia and would thus inform any teleological interpretation in accordance with the object and purpose of the Statute. The Appeals Chamber noted that, "whenever a literal interpreta-

107. In re Indictment, Case No. STL-11-01/I, Interlocutory Decision on the Applicable Law: Terrorism, Conspiracy, Homicide, Perpetration, Cumulative Charging, If 27 (quoting Kosovo Advisory Opinion, supra note 106, If 94).

108. U.N. Secretary-General, Report of the Secretary-General on the Establishment of a Special Tribunal for Lebanon, from the Secretary-General to the Security Council, II 4, 7, U.N. Doc. S/2006/893 (Nov. 15, 2006) [hereinafter Report of the Secretary-General].

109. In $r e$ Indictment, Case No. STL-11-01/I, Interlocutory Decision on the Applicable Law: Terrorism, Conspiracy, Homicide, Perpetration, Cumulative Charging, III 27, 32 n. 48 .

110. Id. I $32 \&$ n. 48 .

111. See id. I 19 "Interpretation is an operation that always proves necessary when applying a legal rule ... . Indeed, the old maxim in claris non fit interpretatio (when a text is clear there is no need for interpretation) is in truth fallacious, as has been rightly emphasized by distinguished scholars.").

112. Id. 
tion of the text" would set particular provisions "at odds" with this identified object and purpose, "an effort must be made to harmonise the various provisions in light of the goal pursued by the legislature."113 In other words, the STL judges should look beyond the most literal interpretations of the Statute's provisions if such interpretations will conflict with the highest international standards of criminal justice.

Second, both bodies of law constitute relevant context for interpreting the provisions regarding proceedings in absentia. The Appeals Chamber has already noted that "the international obligations undertaken by Lebanon," 114 such as its adherence to the ICCPR, ${ }^{115}$ are contextually relevant to a proper interpretation of the Statute. It has also noted, in light of the ICJ's Kosovo opinion, that the Secretary General's report on the STL provides particularly relevant context for interpreting the Statute. ${ }^{116}$ In that report, the Secretary General remarked that Article 22 regarding trials in absentia "takes account of the relevant case law of the European Court of Human Rights, which determined the regularity of trials in absentia in full respect for the rights of the accused," and cited two significant ECtHR decisions on the issue. ${ }^{117}$ The report thus suggests that the Statute's drafters, and the U.N. Security Council in adopting it, intended to align Article 22 with ECtHR case law.

Finally, if any doubt remained about the general approach the STL judges will take towards implementing trials in absentia, the Appeals Chamber has noted it is authorized, "when the Statute or the Lebanese Criminal Code is unclear and when other rules of interpretation have not yielded satisfactory results," to construe the Statute in the manner "which is more favourable to the rights of the suspect or the accused." 118

Adhering to these interpretive principles, the STL judges could not adopt an interpretation of the Statute that would infringe on

113. Id. I 30.

114. Id. I 20.

115. Lebanon acceded to the ICCPR on November 3, 1972. Status of the International Covenant on Civil and Political Rights, United Nations Treaty Collection, http://treaties. un.org $/$ pages $/$ ViewDetails . aspx?src $=$ TREATY\&mtdsg_no $=\Gamma-4 \&$ chapter $=4 \&$ lang $=$ en (last visited Oct. 9, 2011).

116. In re Indictment, Case No. STL-11-01/I, Interlocutory Decision on the Applicable Law: Terrorism, Conspiracy, Homicide, Perpetration, Cumulative Charging, I 27.

117. Report of the Secretary-General, supra note 108, I 33 (citing Sejdovic v. Italy, 2006-II Eur. Ct. H.R. 241, and Krombach v. France, 2001-II Eur. Ct. H.R. 37).

118. In re Indictment, Case No. STL-11-01/I, Interlocutory Decision on the Applicable Law: Terrorism, Conspiracy, Homicide, Perpetration, Cumulative Charging, Il 32. 
the rights of defendants tried in their absence, as recognized by the U.N. Human Rights Committee and the ECtHR, if any other reasonable interpretation of the Statute were possible.

As for the Rules, this interpretive approach applies even more forcefully. The Rules themselves provide that they must be interpreted:

in a manner consonant with the spirit of the Statute and, in order of precedence, (i) the principles of interpretation laid down in customary international law as codified in Articles 31, 32 and 33 of the Vienna Convention on the Law of Treaties (1969), (ii) international standards on human rights (iii) the general principles of international criminal law and procedure, and, as appropriate, (iv) the Lebanese Code of Criminal Procedure. 119

If any ambiguity remains, the judges must adopt that interpretation of the Rules which is "the most favourable to any relevant suspect or accused." 120 Every one of these modes of interpretation would suggest that the Tribunal's Rules regarding trials in absentia should be interpreted in accordance with the highest international standards of criminal justice.

\section{Interpreting Article 22 in Light of STL Jurisprudence}

In determining whether to proceed in the absence of the defendants, the STL Trial Chamber will be guided by the STL's Rules, ${ }^{121}$ but its primary task will be to interpret Article 22. That Article, and thus the decision to proceed with a trial in absentia, requires consideration of three factual elements: waiver, notice, and representation.

\section{A. Waiver: Article 22(1)}

Article 22(1) states that the STL "shall conduct trial proceedings in the absence of the accused" if one of three conditions is met: when the accused expressly waives his right to be present; absconds or cannot be found; or is not brought before the court despite having been provided notice. ${ }^{122}$ In the first situation, the accused

119. Rules of Procedure and Evidence, supra note 23, r. 3(A); see also Statute, supra note 2, art. 28(2) (in adopting Rules of Procedure and Evidence, "the judges shall be guided, as appropriate, by the Lebanese Code of Criminal Procedure, as well as by other reference materials reflecting the highest standards of international criminal procedure, with a view to ensuring a fair and expeditious trial").

120. Rules of Procedure and Evidence, supra note 23, r. 3(B).

121. See id. rs. 105 bis, 106.

122. Statute, supra note 2, art. 22(1). 
explicitly waives his right to be present, while in the latter situations the accused is considered to have implicitly waived this right. Under Rule 105bis(A) and Rule 106(A), the Trial Chamber must determine that one of these three conditions exists before it can authorize proceedings in absentia.

\section{Article 22(1)(a)}

In the most straightforward case, the Trial Chamber can institute proceedings in absentia if the accused "[h] as expressly and in writing waived his or her right to be present." 123 The Statute and Rules are silent regarding what constitutes a waiver of the right to be present, however. The interpretive framework described above requires that any waiver, whether explicit (as required by Article 22(1)(a)) or inferred (as it may be under Article 22(1)(b) and 22(1) (c)), be voluntary, unequivocal, and informed.

This tripartite requirement reflects the highest international standards of criminal justice as repeatedly stated by the ECtHR and the international criminal tribunals. ${ }^{124}$ It also aligns with the requirement under the STL's own Rules that the Trial Chamber be "satisfied" that a guilty plea-another waiver by the defendant of fair trial rights-is voluntary, informed, and unequivocal. ${ }^{125}$

123. Id. art. 22(1) (a).

124. See, e.g., Sejdovic v. Italy, 2006-II Eur. Ct. H.R. 241, II 86-87 (“[A] waiver of the right to take part in the trial must be established in an unequivocal manner and be attended by minimum safeguards commensurate with its importance"; in particular, to establish an "implicit" waiver, "it must be shown that [the accused] could reasonably have foreseen what the consequences of his conduct would be"); Jones v. United Kingdom, App. No. 30900/02, 37 Eur. H.R. Rep. 269, 279 (2003) (defendant must "unequivocally and intentionally" waive his right to attend, which requires awareness of the consequences of failing to appear at trial); Nahimana v. Prosecutor, Case No. ICTR-99-52-A, Judgement, II 109 (Nov. 28, 2007) ("[W]aiver by an accused of his right to be present at trial must be free and unequivocal (though it can be express or tacit) and done with full knowledge. In this latter respect, the Appeals Chamber finds that the accused must have had prior notification as to the place and date of the trial, as well as of the charges against him or her. The accused must also be informed of his/her right to be present at trial and be informed that his or her presence is required at trial.") (footnote omitted). The ICC allows an accused to waive his right to attend his confirmation hearing, but Rule 124 of the ICC Rules of Procedure and Evidence requires the Pre-Trial Chamber to first ensure that the accused understands his right to be present and the consequences of his waiver. Assembly of State Parties to the International Criminal Court, Rules of Procedure and Evidence, 1st Sess., Sept. 3-10, 2002, r. 124, ICC-ASP/1/3 (2002). This procedure was followed when Germaine Katanga chose to waive his right to attend part of his confirmation hearing in July 2008. Peter Robinson, Trial in Absentia at the International Criminal Tribunal for Rwanda, in ProteCtiNo Humanity: Essays in International. Law and Policy in Honour of Navanethem Pillay 643, 655 (Chile Eboe-Osuji ed., 2010).

125. Rule 100(A) of the Rules of Procedure and Evidence provides: 
What circumstances will demonstrate that a waiver is voluntary, informed, and unequivocal will vary depending on the case. Particularly when the waiver is implicit, the finding of a waiver may be based in part on inferences. ${ }^{126}$ In Article 22(1) (a) situations, however, this finding may rely primarily, even solely, on the fact that the waiver is written and explicit. ${ }^{127}$

2. Article 22(1)(c)

Article 22(1) (c) allows trials in absentia when the accused "[ $\mathrm{h}]$ as absconded or otherwise cannot be found and all reasonable steps have been taken to secure his or her appearance before the Tribunal and to inform him or her of the charges confirmed by the PreTrial Judge."128 "Absconded" is not a general term synonymous with "absent," but instead requires the actor " $[t]$ o depart secretly or suddenly, esp[ecially] to avoid arrest, prosecution, or service of process," or "[t]o leave a place."129 Article 22(1)(c), then, covers situations in which the defendant has actively fled or his whereabouts are otherwise unknown; it does not extend to situations in which the defendant continues to reside openly at home, relying on the state's unwillingness to cooperate with the Tribunal by arresting him. ${ }^{130}$

The act of absconding is an implicit waiver of the right to be present: if the defendant knows of the pending proceedings but flees, he has chosen not to exercise his right to defend himself in person. This chain of reasoning requires that the defendant is at

If an accused pleads guilty in accordance with Rule 98, or requests to change his plea to guilty, and the Trial Chamber is satisfied that: (i) the guilty plea has been made voluntarily; (ii) the guilty plea is informed; (iii) the guilty plea is unequivocal; and (iv) there is a sufficient factual basis for the crime and the accused's participation in it . . . the Trial Chamber may enter a finding of guilt and set a date for the sentencing hearing.

Rules of Procedure and Evidence, supra note 23, r. 100(A).

126. See, e.g., Demebukov v. Bulgaria, App. No. 68020/01, 50 Eur. H.R. Rep. 1040, I 57 (2008) (inferring effective waiver where defendant had assistance of counsel, knew of the ongoing criminal investigation, and had failed to comply with order to inform the public prosecutor's office if he left his village); see also Taylor v. United States, 414 U.S. 17, 20 (1973) (per curiam) (inferring effective waiver based on presumed knowledge that the trial would continue without the defendant present).

127. Cf. Battisti v. France, App. No. 28796/05, Eur. Ct. H.R., Decision on Admissibility (Dec. 12, 2006), available at http://www.echr.coe.int/echr/ (inferring waiver where the defendant had designated his counsel in writing).

128. Statute, supra note 2, art. 22(1)(c).

129. Black's LAW Dictionary 7 (9th ed. 2010) (emphasis added). The French version of Article 22(1) (c) is similarly clear, covering instances where the accused "est en fuite ou est introuvable." Statut du Tribunal spécial pour le Liban, S.C. Res. 1757, Annex, art. 22(1)(c), U.N. Doc. S/RES/1757 (May 30, 2007).

130. See discussion infra Part V.A.3. 
least aware of the charges. Waiver cannot be inferred if the defendant has no reason to know of the indictment and might have left his home or disappeared from public view for entirely innocent reasons. ${ }^{131}$ It is even more difficult to infer a waiver from the fact that the defendant's whereabouts are simply unknown. Thus Article 22(1) (c) specifies that the Tribunal must first take "all reasonable steps" to secure the defendant's appearance and inform him of the charges against him.

Because it is phrased in terms of the Tribunal's conduct, however, this "all reasonable steps" condition in Article 22(1)(c) does not necessarily require a finding that the steps taken were successful. The requirement that the defendant actually receive notice, whether through formal service or indirect awareness, is instead embodied in Article 22(2)(a), which will be discussed further below. ${ }^{132}$ That the Tribunal took all reasonable steps to inform the accused of the charges against him will often (if not always) be a necessary condition to finding that the accused had adequate knowledge of the indictment, ${ }^{133}$ but it may not by itself be sufficient-that is, it may be that additional evidence will be required to prove that the accused was actually aware of the charges. The "all reasonable steps" finding under Article 22(1)(c) should thus be treated as a separate determination from whether notice has been achieved under Article 22(2) (a).

What are "all reasonable steps"? It will be in the Tribunal's interest to apply this requirement fairly strictly, thereby minimizing potential grounds for a retrial. ${ }^{134}$ First, in light of comments from the U.N. Human Rights Committee and the ECtHR, the judges should require that the Tribunal, meaning the prosecutor and the Registrar, diligently pursue all leads available to locate the defendant. ${ }^{135}$ In parallel, the Tribunal must pursue all avenues of coop-

131. See, e.g., Sejdovic v. Italy, 2006-II Eur. Ct. H.R. 241, II 100-01; see also id. II 87-88 (citing Colozza v. Italy, 89 Eur. Ct. H.R. (ser. A) at 14 (1985)).

132. See discussion infra Part V.B.1.

133. The U.N. Human Rights Committee seems to treat the diligence of prosecuting authorities in attempting to notify the accused as a necessary precondition before it will reach the question of whether the notice was in fact sufficient. See, e.g., U.N. Human Rights Comm., Osiyuk v. Belarus, II 8.2-8.3, U.N. Doc. CCPR/C/96/D/1311/2004 (Aug. 21, 2009); U.N. Human Rights Comm., Salikh v. Uzbekistan, II 9.5, U.N. Doc. CCPR/C/ 95/D/1382/2005 (Apr. 22, 2009). The ECtHR has faulted government authorities for failing to take all reasonable steps to notify the defendant through formal service even though it acknowledged that the defendant had learned about the proceedings indirectly. See T v. Italy, 245 Eur. Ct. H.R. (ser. A) at 42 (1992).

134. See discussion infra Part VI.

135. See, e.g., U.N. Human Rights Comm., Mbenge v. Zaire, II 14.2, U.N. Doc. CCPR/ C/OP/2 (Mar. 25, 1983) (authorities failed to serve claimant at known address); T. v. Italy, 
eration with states on whose territory the defendant may be residing. Second, Rule 76 bis calls for the indictment's "publication in newspapers and/or for broadcast via radio, television and/or other media, including the internet,"136 which suggests the Tribunal should ensure the indictment's advertisement through all available media outlets. This effort should be conducted in conjunction with alternative methods of service required by the relevant domestic law when a defendant cannot be served in person. For example, under Lebanese procedure for trials in absentia, the summons should be served "by way of publication and by posting it for a period of ten days at the entrance to [the accused's] last place of residence, displaying it in the public square of [the accused's] town or village, and posting it at the entrance to the courtroom."137 Service in Lebanon can also be effected by leaving the indictment with a family member. ${ }^{138}$ While this would not satisfy the STL's "personal service" requirement, ${ }^{139}$ it would nonetheless be a "reasonable" step (under Article 22(1)(c)) towards informing the defendant of the charges against him when personal service has failed.

\section{Article 22(1)(b)}

Finally, under Article 22(1) (b), the STL "shall" conduct a trial in absentia when the accused "has not been handed over to the Tribunal by the State authorities concerned." 140 It is unfortunate that this provision is phrased in terms of state action rather than in terms of the accused's conduct, which obscures its meaning. ${ }^{141}$ When contrasted to Article 22(1)(c), however, it is clear that Article 22(1) (b) refers to the scenario in which the defendant does not flee from justice or go into hiding, but instead continues as normal

245-C Eur. Ct. H.R. (ser. A) at 42 (authorities did not follow up on available information that claimant was living in Sudan); F.C.B. v. Italy, 208-B Eur. Ct. H.R. (ser. A) at 21 (1991) (authorities failed to serve claimant personally even though Dutch authorities, claimant's counsel, and two co-defendants had all stated that claimant was being detained in a Dutch prison). But see Demebukov v. Bulgaria, App. No. 68020/01, 50 Eur. H.R. Rep. 1040, I 57 (2008) (authorities not required to take all feasible steps to locate the defendant where defendant failed to comply with specific order to inform authorities of his movements).

136. Rules of Procedure and Evidence, supra note 23, r. 76bis (emphasis added).

137. Act No. 328 of 7 Aug. 2001 (New Code of Criminal Procedure), art. 284 (Leb.).

138. Id. art. 147.

139. See Rules of Procedure and Evidence, supra note 23, r. 76(B).

140. Statute, supra note 2, art. 22(1) (b). Rule 106(A) (ii) adds to this the caveat "within a reasonable time." Rules of Procedure and Evidence, supra note 23, r. 106(A) (ii).

141. As for why Article 22(1)(b) may have been written in terms of state action, see Elberling, supra note 6, at 531,537-38 (suggesting Article 22 reflects a presumption that Syria and Syrian authorities would be implicated in the cases before the Tribunal). 
and relies on the governing authority's unwillingness to cooperate with the Tribunal by arresting him (for the Tribunal, like all international criminal courts, is fully dependent on the cooperation of state authorities to seize individuals on their territory). ${ }^{142}$ The waiver in this instance would be inferred from the defendant's failure to voluntarily turn himself in to the Tribunal.

Critics have argued, however, that this provision requires trial in absentia when a defendant wishes to attend his trial but the state prevents him from doing so, in which case his absence would be due to circumstances beyond his control. ${ }^{143}$ The critics are correct that such an outcome would be unacceptable. ${ }^{144}$ The legitimacy of proceedings in absentia is premised on the defendant's informed choice not to attend his own trial. From the IMT's refusal to continue a trial in light of a defendant's failing health ${ }^{145}$ to the ECtHR's holding that a court could not try in absentia a defendant jailed in another jurisdiction, ${ }^{146}$ international courts have consistently emphasized that respect for the defendant's choice to attend his trial must take precedence over expediency and even over the orderly administration of justice. Likewise, under Lebanese criminal procedure, the court at least has the discretion to consider the defendant's excuse for his absence, to verify its validity, and to defer proceedings as necessary. ${ }^{147}$

Although a guaranteed right of retrial can alleviate human rights concerns, the right of retrial specified in Article 22(3) may not provide an adequate remedy in this situation. Whether and how the

142. Wayne Jordash and Tim Parker are particularly critical of Article 22(1)(b), but one of their concerns- that the relevant state would be unknown if the defendant's whereabouts are unknown-is resolved if one understands that Article 22(1)(c) and not Article 22(1) (b) applies in that situation. See Jordash \& Parker, supra note 6, at 495.

143. See, e.g., Elberling, supra note 6, at 536-38; Gaeta, supra note 6, at 1171-72; Jordash \& Parker, supra note 6, at 497; Pons, supra note 6, at 1311-14; Schabas, supra note 1 , at 379 .

144. For a different view on the matter, see Riachy, supra note 57, at 1300-01 (suggesting application of Article 22(1)(b) in such circumstances would be acceptable).

145. See Schabas, supra note 1, at 342-50 (describing the case of Gustav Krupp van Bohlen, in which the International Military Tribunal at Nuremburg concluded, "[w]here nature rather than flight or contumacy has rendered such a trial impossible, it is not in accordance with justice that the case should proceed in the absence of a defendant").

146. See F.C.B. v. Italy, 208 Eur. Ct. H.R. (ser. A) at 21 (1991); Demir v. Italy, App. No. 25381/02, Eur. Ct. H.R., Judgement, II 40-43 (July 28, 2009), available at http://www. echr.coe.int/echr/ (the absence at trial of a defendant serving compulsory military service did not constitute a voluntary waiver of the right to be present).

147. See Act No. 328 of 7 Aug. 2001 (New Code of Criminal Procedure), art. 285 (Leb.). Regarding the relevancy of the Lebanese Code of Criminal Procedure, see Report of the Secretary-General, supra note 108, II 33 (noting that Article 22 acts "en complément de la procédure pénale libanaise" regarding trials in absentia). 
right of retrial under Article 22(3) may actually be invoked is subject to some debate, as will be discussed further below. ${ }^{148}$ Further, proceeding with a trial despite the absent defendant's wishes, regardless of any later right to retrial, exposes the defendant to a host of undesirable costs, not the least of which may be unnecessary reputational harm. If a state refuses to allow a defendant to attend his trial at the STL against the defendant's wishes, then the just outcome may be for the STL to defer proceedings, perhaps indefinitely.

But this debate may, in practice, prove much ado about very little. The text of Article 22(1)(b) does not explicitly extend to instances in which a state is preventing the defendant from attending trial. While one could argue that the provision implicitly reaches such instances (given the imprecision with which it was written), such an interpretation would be contrary to the highest international standards of criminal justice and would violate the Statute's overarching purpose of achieving justice in a fair and efficient manner. On the other hand, Article 22(1) (b) can be interpreted as implicitly limited to those situations where the defendant's whereabouts are known, in contrast to Article $22(1)(c)$, but the state on whose territory he is residing will not arrest him and he refuses to surrender voluntarily. This interpretation (i) renders Article 22(1) (b) effective ${ }^{149}$ by covering a scenario that is likely to arise but is not otherwise accounted for in Article 22(1) while (ii) aligning Article 22(1) (b) with universally recognized fair trial rights, thereby (iii) best harmonizing the sub-provisions of Article 22 with each other and with the Statute as a whole. ${ }^{150}$

In other words, Article 22(1)(b) does not directly state that it applies in situations where the state is preventing the defendant from surrendering voluntarily; either way, further interpretation is necessary. Interpreting the provision to exclude situations in which the accused is prevented from attending trial retains an independent purpose for the provision while aligning it with international human rights jurisprudence. Thus, pursuant to the framework set forth in the Rule 176 bis Decision, this is the interpretation the judges would have to adopt.

148. See discussion infra Part V.C.

149. Cf. In re Indictment, Case No. STL-1 1-01/I, Interlocutory Decision on the Applicable Law: Terrorism, Conspiracy, Homicide, Perpetration, Cumulative Charging, If 30 (Feb. 16, 2011) (describing the principle of effectiveness and emphasizing its importance in interpretation).

150. See id. 
Indeed, international human rights law is so clear that a defendant cannot be tried in his absence if he is prevented from attending the trial due to circumstances beyond his control, the STL judges could refuse to conduct a trial in absentia under such circumstances even if one were explicitly mandated by the Statute, . That is, even if there were no reasonable interpretation of Article 22(1) (b) that would avoid this situation (as there is), the judges could resort to the Tribunal's inherent power to refuse to exercise an enumerated procedural power so as to "to ensure a good and fair administration of justice, including full respect for human rights." 151 While some scholars have warned of the greater theoretical issues that could arise if a court established by the U.N. Security Council exercised "judicial review" to decline the scope of powers granted by the Security Council, ${ }^{152}$ this would be a more narrow issue: declining to exercise a procedural power if, in particular and rare circumstances, it would be contrary to the interests of justice to do so. The U.N. Security Council has created an independent court and granted it a scope of authority bounded by some general rules; that court has inherent power to apply those rules consistently and coherently, including to resolve conflicts with other controlling rules (such as the ICCPR). ${ }^{153}$ Indeed, as the ICTY has recognized, international tribunals such as the STL must "provide all the guarantees of fairness, justice and even-handedness, in full conformity with internationally recognized human rights instruments." 154

It is worth noting that the Appeals Chamber has already set the stage for the Tribunal to employ this line of reasoning. In its Rule

151. In re El Sayed, Case No. CH/AC/2010/02, Decision on Appeal of Pre-Trial Judge's Order Regarding Jurisdiction and Standing, I 45 (Special Tribunal for Leb. Nov. 10, 2010).

152. See, e.g., Marko Milanovic, An Odd Couple: Domestic Crimes and International Responsibility in the Special Tribunal for Lebanon, 5 J. INT'L CRIM. Just. 1139, 1150 \& n.42 (2007) (gathering sources on this debate). But see Prosecutor v. Tadic, Case No. IT-94-1-AR72, Decision on the Defence Motion for Interlocutory Appeal on Jurisdiction, II 14-22 (Int'l Crim. Tribunal for the Former Yugoslavia Oct. 2, 1995) (concluding that the ICTY had inherent jurisdiction to determine whether its very establishment by the U.N. Security Council was invalid).

153. See El Sayed, Case No. CH/AC/2010/02, Decision on Appeal of Pre-Trial Judge's Order Regarding Jurisdiction and Standing (generally discussing the courts' inherent powers); In re Indictment, Case No. STL-11-01/1, Interlocutory Decision on the Applicable Law: Terrorism, Conspiracy, Homicide, Perpetration, Cumulative Charging, I 23 (noting the need for the interpreter of a statute to "give consistency, homogeneity and due weighting to the different elements of a diverging or heterogeneous set of provisions").

154. Tadic, Case No. IT-94-1-AR72, Decision on the Defence Motion for Interlocutory Appeal on Jurisdiction, It 45. 
176bis Decision, the Appeals Chamber acknowledged that Article 2 of the Statute, which requires the Tribunal to apply the substantive criminal law of Lebanon, conflicts in some respects with Article 3, which spells out modes of criminal responsibility as they have developed in international criminal law. ${ }^{155}$ Regarding forms of criminal participation (e.g., co-perpetration and joint criminal enterprise), the Appeals Chamber concluded that the Tribunal should resolve any specific conflict between the two Articles by applying the law (Lebanese or international) that is most favorable to the accused. ${ }^{156}$ This analysis sets up the likelihood-and acceptability-of the Tribunal refusing to exercise the full scope of its powers under Article 3 when doing so would lead to retroactivity problems or other infringements of defendants' rights. ${ }^{157}$

The same reasoning demonstrates that the chapeau of Article 22(1), which states that the Tribunal "shall conduct trial proceedings in the absence of the accused," 158 will not force the Tribunal to act in violation of international law and universally recognized fair trial rights, as some have argued. ${ }^{159}$ As a preliminary matter, Article 22 only calls for trials in absentia when all the conditions of Article 22(1) and (2), both explicit and implicit, are met. If the judges indeed adopt interpretations of those conditions as forecasted here, trials in absentia should only be required in limited circumstances and in accordance with international human rights standards. But if complying strictly with the terms of Article 22 would ever result in violating fair trial rights, the Tribunal's judges could be expected to invoke their inherent power to stay proceedings or otherwise decline to move forward with a trial in absentia. ${ }^{160}$

155. See In re Indictment, Case No. STL-1 1-01/I, Interlocutory Decision on the Applicable Law: Terrorism, Conspiracy, Homicide, Perpetration, Cumulative Charging, II 204-07.

156. Id. I 211; see also id. I 262 (providing an additional example).

157. Cf. Milanovic, supra note $152,1142-43$ (analyzing the legality problems that may arise if the STL applies the superior orders provision of Article 3 in excess of pre-existing Lebanese law).

158. Statute, supra note 2, art. 22(1) (emphasis added).

159. See Jordash \&c Parker, supra note 6, at 495.

160. On the growing recognition of the human rights obligations of international tribunals, see Guido Acquaviva, Human Rights Violations Before International Tribunals: Reflections on Responsibility of International Organizations, 20 LEIDEN J. INT'L L. 613, 614-21 (2007). Indeed, the French version of Rule 106 reflects the non-mandatory nature of trials in absentia when it states that, if the conditions of Rule 106(A) (which are the same as Article 22(1)) have been met, the Trial Chamber "can decide [peut décider]" to institute trial proceedings in absentia. Reglement de Procédure et de Preuve, supra note 86, r. 106. The English version, which reads "the Trial Chamber shall conduct proceedings in absentia," is similar to the Arabic version. Rules of Procedure and Evidence, supra note 23, r. 106. The 
As a final note, if the Trial Chamber invokes Article 22(1)(b) as the grounds for proceeding in absentia, it must also "consult with the President and ensure that all necessary steps have been taken with a view to ensuring that the accused may, in the most appropriate way, participate in the proceedings." 161 Wayne Jordash and Tim Parker argue that this provision suggests the STL judges are prepared to try in absentia defehdants who are prevented from exercising their right to attend. ${ }^{162}$ Their concern appears to be based primarily on Rule 106(B)'s failure to explicitly exclude such a possibility. ${ }^{163}$ While they are correct that the STL judges missed an opportunity with Rule 106(B) to clarify that Article 22(1)(b) does not extend to circumstances in which a defendant is prevented from attending trial, those same judges have made clear that they will interpret the Statute in accordance with international human rights standards. ${ }^{164}$ Under that interpretive approach, as this Article argues, defendants who are prevented from attending their trials by States or other external forces would fall outside the scope of Article 22(1)(b) -and thus also outside the scope of Rule $106(\mathrm{~B})$.

What Rule 106(B) instead reflects is a broader effort through the Rules to allow hesitant defendants to participate in their trials from afar. The Rules demonstrate a desire to balance the truth-seeking function of trials (which purpose is furthered by the defendant's willing participation) and the difficult reality that some defendants will refuse to surrender to the Tribunal if the only option is lengthy detention by a court whose legitimacy they do not accept. Thus the Rules allow defendants, in some instances, to attend court hearings while not in custody and even to participate in hearings via video-conference. ${ }^{165}$

In this sense, the STL is in the vanguard of international criminal law by allowing a voluntarily absent defendant to nonetheless participate extensively in his defense-indeed, to participate to the greatest extent feasible. The ECtHR, for example, allows more leeway for states to "discourage unjustified absences" by limiting absent defendants' ability to participate in their trials, as long as

author believes the STL judges should apply the French version in this situation as more protective of the rights of the defendant.

161. Rules of Procedure and Evidence, supra note 23, r. 106(B) (i).

162. Jordash \& Parker, supra note 6, at 497.

163. Id.

164. See discussion supra Part IV.B.

165. Rules of Procedure and Evidence, supra note 23, rs. 103, 105. 
those sanctions are proportionate to the circumstances of the case and do not include depriving the defendants of representation. ${ }^{166}$

If a voluntarily absent defendant takes advantage of these opportunities at the STL to participate in his defense from afar, however, he effectively waives his right to be physically present, including any guaranteed right to a retrial. This outcome is formalized through Rule 104.

\section{Rule 104}

Rule 104, titled "Waiver of the Right to Attend Proceedings," provides:

Once an accused has appeared before the Tribunal in person, by video-conference, or by Counsel appointed or accepted by him, without having expressly and in writing waived his right to be present at proceedings before the Tribunal, the proceedings shall not be deemed to be in absentia pursuant to Article 22 of the Statute.

That is, if a physically absent defendant opts to participate in his defense, he has forfeited the procedural protections provided under Article 22 for trials in absentia. This approach is logical when considered from the perspective of a defendant who makes an informed decision as to the degree to which he chooses to participate in his trial. It also prevents a voluntarily absent defendant from abusing the system by appearing through a lawyer or by videoconference only to make a political statement, denounce the Tribunal, or otherwise undermine the legitimacy of the proceedings.

The interplay between Article 22 and Rule 104 is, however, concerning. Under Rule 104, a defendant who appears before the Tribunal in person, by video-conference, or by counsel "appointed or accepted by him" has waived his right to be present for the duration of his trial, with no right of retrial as a guaranteed remedy should the presumption of waiver be ill-founded. Thus, before invoking Rule 104, the judges should ensure that the defendant understands the consequences of his decision to participate and is voluntarily choosing not to attend the rest of his trial一in other words, that the waiver of attendance be informed, voluntary, and unequivocal. ${ }^{167}$

A hypothetical, albeit a rather unlikely one, will help illustrate the complications that may arise from application of Rule 104. Consider a defendant who is being detained by a country that will

166. See, e.g., Sejdovic v. Italy, 2006-II Eur. Ct. H.R. 241, II 92.

167. See discussion supra Part V.A.1. 
not surrender him to the STL but who nonetheless wishes to be physically present for his trial. He sends an attorney to the STL to explain his situation. Has he therefore "appeared before the Tribunal . . . by Counsel appointed or accepted by him," such that a trial could then proceed in his continued absence yet not be covered by the safeguards of Article 22? The answer must be no. It would not be difficult for the judges to ensure the indisputably just result in this hypothetical situation: Rule 104 does not prevent the judges from suspending proceedings until the defendant can appear in person, if they deem such a stay to be in the interests of justice, nor does Article 22(3) prevent the judges from ordering retrials in situations beyond the mandatory scope of that provision. That is, Article 22(3) defines circumstances when retrials must be provided, but does not limit when they may be provided. Even so, leaving so much to the discretion of the judges places the burden of unpredictability on the defense and has understandably drawn criticism. ${ }^{168}$ It is unclear how a defense counsel should most ethically act in this hypothetical situation to best protect her client's interests without risking the forfeiture of any of her client's rights. The STL judges should consider revising Rule 104, or at least clarify as early as possible how the Rule will be applied in conformity with the highest international standards of criminal justice.

\section{B. Notice and Representation: Article 22(2)}

In addition to determining that one of the conditions of Article 22(1) has been met and that the defendant has therefore effectively waived his right to be present, the Trial Chamber must also satisfy itself that the accused has received adequate notice of the indictment and that he is represented by counsel in his absence. ${ }^{169}$

168. See, e.g., Jordash \& Parker, supra note 6, at 508.

169. Statute, supra note 2 , art. 22(2). Oddly, Rule 106(B) explicitly requires the Trial Chamber to "ensure that the requirements of Article 22(2) of the Statute have been met" only when it the defendant is absent because of "the failure or refusal of the relevant State to hand him over," which seems to limit the requirement to Article 22(1)(b) circumstances. See Rules of Procedure and Evidence, supra note 23, r. 106(B). Article 22(2) by its terms clearly requires the judges to ensure its conditions are met in all instances where proceedings in absentia are contemplated. See Statute, supra note 2, art. 22(2). Of course, notice can be assumed when a defendant has expressly and in writing waived his right to be present under Article 22(1)(a), a waiver that, as has already been argued, must be fully informed. See discussion supra Part V.A.1. But ensuring that "all reasonable steps have been taken" to inform the accused of the charges, pursuant to Article 22(1)(c), is not necessarily equivalent to providing effective notice as required by Article 22(2)(a). See Statute, supra note 2, art. 22(2) (a), 22(1) (c); see also discussion supra Part V.A.2. The Trial Chamber should thus take care to apply Article 22(2), particularly the notice requirement 


\section{Notice}

Before proceeding in the defendant's absence, the Tribunal must ensure that " $[\mathrm{t}]$ he accused has been notified, or served with the indictment, or notice has otherwise been given of the indictment through publication in the media or communication to the State of residence or nationality." 170 Some commentators have suggested that the phrase "notice has otherwise been given" does not require the defendant to have actual knowledge of the indictment. ${ }^{171}$ Such an interpretation is not the most persuasive reading of the text; it would also be unsupportable under the interpretive framework now established by the Appeals Chamber.

As a textual matter, if the drafters would have been satisfied with the Tribunal simply advertising the indictment or communicating it to the relevant states, there would be no need for the phrase "notice has otherwise been given." Instead, the provision could have been written, like Article 22(1)(c), solely in terms of the Tribunal's conduct (e.g., "or the indictment has been published in the media or communicated to the State of residency or nationality"). By including the concept of notice, the drafters signaled an interest in the effect of the advertisement and transmittal of the indictment.

Under the highest international standards of criminal justice, in accordance with which the STL judges must interpret Article 22, ${ }^{172}$ the necessary effect must be actual notice, meaning that the defendant has become aware of the charges and the trial, whether through formal service or through indirect channels. The U.N. Human Rights Committee has commented that " $[\mathrm{p}]$ roceedings in the absence of the accused may in some circumstances be permissible in the interest of the proper administration of justice, i.e. when accused persons, although informed of the proceedings sufficiently in advance, decline to exercise their right to be present." 173 In particular, "the necessary steps [must be] taken to summon accused per-

of Article 22(2)(a), in all circumstances before proceeding to trial in the absence of a defendant.

170. Statute, supra note 2, art. 22(2) (a).

171. See Gaeta, supra note 6, at 1168-69 (assuming Article 22(2)(a) would be satisfied as long as the indictment is publicized or communicated to relevant States); Jenks, supra note 6, at 81, 96 (concluding that the "notice otherwise given" language does not require actual notice, in violation of the ICCPR and the European Convention); see also Jordash \& Parker, supra note 6, at 496-97 (noting Article 22(2) (a) could be interpreted in this fashion, but rejecting that interpretation as contrary to international standards for fair trials).

172. See discussion supra Part IV.B.

173. General Comment No. 32, supra note 50, I 36 (emphasis added). 
sons in a timely manner and to inform them beforehand about the date and place of their trial and to request their attendance."174

In its early views in Mbenge v. Zaire, ${ }^{175}$ the U.N. Human Rights Committee acknowledged "there must be certain limits to the efforts which can duly be expected of the responsible authorities of establishing contact with the accused."176 This, however, was dicta relating to a situation in which the authorities had made no efforts to notify the defendant. ${ }^{177}$ While there are limits to what prosecuting authorities and the courts can do to notify an accused of a trial, there should still be some basis for believing that the steps taken succeeded in making the accused aware of the trial and of his rights. ${ }^{178}$ Otherwise, the inference that the accused has waived his right to be present would be based on a presumption that the accused was even aware his presence was required; this double presumption is a very unstable basis on which to override fundamental fair trial rights. In Maleki v. Italy, the U.N. Human Rights Committee clarified that a court hearing a trial in absentia must "verify that the [accused] had been informed of the pending case before proceeding," 179 thereby affirming that actual notice is required.

The ECtHR has been even clearer that notice "must be carried out in accordance with procedural and substantive requirements capable of guaranteeing the effective exercise of the accused's rights; vague and informal knowledge cannot suffice." 180 In $T . v$. Italy, the Court went so far as to find a violation of fair trial protections where it concluded that a defendant had received indirect notice of criminal proceedings, as demonstrated through letters he had written to his wife, but where the authorities had not taken all reasonable and diligent steps to inform the defendant of the charges through formal procedures. ${ }^{181}$ All the same, T. v. Italy does not foreclose the possibility that the defendant may receive

174. Id.

175. U.N. Human Rights Comm., Mbenge v. Zaire, U.N. Doc. CCPR/C/OP/2 (Mar. $25,1983)$.

176. Id. I 14.2.

177. Id:; see also, e.g., U.N. Human Rights Comm., Osiyuk v. Belarus, II 8.3, U.N. Doc. CCPR/C/96/D/1311/2004 (Aug. 21, 2009); U.N. Human Rights Comm., Salikh v. Uzbekistan, II 9.5, U.N. Doc. CCPR/C/95/D/1382/2005 (Apr. 22, 2009).

178. To reiterate, it is argued here that the former-the requirement that the authorities make all feasible efforts to notify an accused-is encompassed by Article 22(1)(c), while the latter-the effectiveness of that notice-is a separate inquiry under Article 22(2)(a).

179. U.N. Human Rights Comm., Maleki v. Italy, I 9.4, U.N. Doc. CCPR/C/66/D/ 669/1996 (July 27, 1999).

180. Sejdovic v. Italy, 2006-II Eur. Ct. H.R. 241, I 99.

181. T v. Italy, 245 Eur. Ct. H.R. (ser. A) at 42 (1992). 
notice indirectly-at least as long as the governing authorities did everything they could to provide formal and direct notice first. While the ECtHR's Grand Chamber in Sejdovic acknowledged the strict holding of T. $v$. Italy, it went on to note:

The Court cannot, however, rule out the possibility that certain established facts might provide an unequivocal indication that the accused is aware of the existence of the criminal proceedings against him and of the nature and the cause of the accusation and does not intend to take part in the trial or wishes to escape prosecution. This may be the case, for example, where the accused states publicly or in writing that he does not intend to respond to summonses of which he has become aware through sources other than the authorities, or succeeds in evading an attempted arrest. . .or when materials are brought to the attention of the authorities which unequivocally show that he is aware of the proceedings pending against him and of the charges he faces. ${ }^{182}$

The U.N. Human Rights Committee has also left open the possibility that adequate notice can be provided indirectly, such as through the defendant's family. ${ }^{183}$ Furthermore, the ECtHR cases relate to more typical criminal prosecutions, not to international criminal trials of high-profile crimes where knowledge of an indictment and the existence of in absentia proceedings may be more readily assumed based on media coverage and public statements of the accused. ${ }^{184}$

Thus the simplest and most logical interpretation of Article 22(2) (a), particularly in light of the Statute's purpose and context, is that the phrase "notice has otherwise been given" requires the defendant have actual knowledge of the indictment, but that the phrase's passive construction permits the fact of knowledge to be established indirectly.

How could indirect knowledge be established? Some countries, including Lebanon, assume notice has been achieved if certain dis-

182. Sejdovic, 2006-II Eur. Ct. H.R. I 99. This dicta is particularly telling, as the First Chamber had seemed to suggest that indirect notice would never be sufficient. See Jordash \& Parker, supra note 6, at 493 (quoting the First Chamber at length).

183. See U.N. Human Rights Comm., Osiyuk v. Belarus, I 8.2, U.N. Doc. CCPR/C/96/ D/1311/2004 (Aug. 21, 2009).

184. While in Somogyi $v$. Italy the ECtHR noted that the Italian government could not assume the accused had learned of the proceedings through the local press, the government in that case had not adduced any actual evidence of press coverage, much less of the accused's awareness of any such press coverage. See Somogyi v. Italy, 2004IV Eur. Ct. H.R. 105, 1156-57, 75; see also Elberling, supra note 6, at $537 \mathrm{n.51}$ (noting that the high profile of the cases before the STL increases the likelihood that defendants will learn of the publication of the indictment through the media). 
tribution and publication requirements are met. 185 The STL, whose procedure is a mix of Lebanese and international law, should apply a more stringent standard in this instance, to ensure conformity with the highest international standards of criminal justice. That certain steps have been taken to advertise the indictment may be evidence that the defendant is likely aware of the charges and the trial, but it may not by itself be sufficient. At the same time, conclusive proof of the defendant's awareness may not be necessary if there are sufficient grounds for inferring such awareness. Such grounds may include widespread media coverage, statements of associates, or knowledge of immediate family members. What standard of proof must be met to establish this finding is an open question: for example, whether the circumstances must indicate it is more probable than not that the defendant received notice, or that the evidence of notice must be clear and convincing, or something in between. Whichever standard is applied, however, the defendant must subsequently be able to challenge that finding. ${ }^{186}$

\section{Representation}

Finally, Article 22(2)(b) and 22(2)(c) require the Tribunal to ensure the defendant is represented by counsel even in his absence. The defendant may "designate[ ] a defence counsel of his or her own choosing," whose services may be paid for by the Tribunal if the defendant is indigent. ${ }^{187}$ Otherwise, Rule 105bis(B) directs the Pre-Trial Judge, before commencing pre-trial proceedings in absentia, to request the Head of the Defence Office to assign counsel. ${ }^{188}$

In this respect, Article 22 is clearly aligned with international standards. The ECtHR has emphasized repeatedly that states may not punish defendants for not showing up to trial by denying them

185. See, e.g., Act No. 328 of 7 Aug. 2001 (New Code of Criminal Procedure), art. 284 (Leb.).

186. See Somogyi, 2004-IV Eur. Ct. H.R. II 72-74.

187. Statute, supra note 2, art. 22(2) (b).

188. See also id. art. 22(2) (c). Uniquely among the international criminal courts, the STL has an independent defense organ charged with "drawing up a list of defence counsel" and "protect[ing] the rights of the defence, provid[ing] support and assistance to defence counsel and to the persons entitled to legal assistance, including, where appropriate, legal research, collection of evidence and advice, and appearing before the Pre-Trial Judge or a Chamber in respect of specific issues." Id. art. 13; see also Rules of Evidence and Procedure, supra note 23, r. 57 (describing the functions of the Head of the Defence Office). 
the right to representation. ${ }^{189}$ Not only does the STL require representation for absent defendants, but it also allows absent defendants to choose to appear for hearings via video-conference. ${ }^{190}$ That is, the STL maximizes the extent to which absent defendants may choose to participate in their defense from afar.

\section{Retrial: Article 22(3)}

Although the question of whether a defendant convicted in absentia by the STL should have a right to a retrial will not arise anytime soon, the foregoing discussion does shed some light on Article 22(3)'s requirement that a defendant convicted in absentia, "if he or she had not designated a defence counsel of his or her choosing, shall have the right to be retried in his or her presence before the Special Tribunal." 191

Under the ICCPR and the ECtHR jurisprudence, a defendant convicted in absentia must have a right to retrial if he did not waive his right to be present ${ }^{192}$ : for example, if he can show he did not receive actual notice of the charges and the date of trial, ${ }^{193}$ or if he was prevented from attending against his will. ${ }^{194}$ A full retrial is not necessarily required, however, as long as the defendant can submit new evidence and the reviewing court is empowered to consider the merits of the case de novo. ${ }^{195}$

If the defendant has designated defense counsel, it follows logically that the defendant had notice of the charges. The greatest potential for concern with the language of Article 22(3), then, is the treatment of a defendant who designates defense counsel but does not intend to waive his right to be present. As ECtHR case law demonstrates, these are two separate and distinct rights. ${ }^{196}$ Consider the possibility of a defendant who is prevented by a state from attending trial at the STL but nonetheless wishes to protect his interests as much as possible via counsel. He would thus designate

189. See Krombach v. France, 2001-II Eur. Ct. H.R. 37, I 89; Poitrimol v. France, 277

Eur. Ct. H.R. (ser. A) at 13 (1993); see also Sejdovic v. Italy, 2006-II Eur. Ct. H.R. 241, I 91.

190. Rules of Procedure and Evidence, supra note 23, r. 105.

191. Statute, supra note 2, art. 22(3); Rules of Procedure and Evidence, supra note 23, rs. 108-09. Article 22(3) is implemented primarily through Rules 108-09.

192. See, e.g., Sejdovic, 2006-II Eur. Ct. H.R. II 82-84.

193. See Somogyi v. Italy, 2004-IV Eur. Ct. H.R. 105, IT 72-74.

194. See F.C.B. v. Italy, 208 Eur. Ct. H.R. (ser. A) at 21 (1991).

195. See, e.g., Jones v. United Kingdom, App. No. 30900/02, 37 Eur. H.R. Rep. 269, 278 (2003).

196. See F.C.B., 208 Eur. Ct. H.R. (ser. A) at 21 (finding defendant had not waived his right to attend trial even though he had designated counsel). 
defense counsel, but would not waive his right to be present. Will he be allowed a retrial under Article 22(3)?

For two reasons, the answer is yes. First, his designated counsel would be able to inform the Tribunal of his client's inability to attend trial. This Article argues that the text of Article 22(1) does not mandate that the Tribunal proceed with a trial in absentia when the defendant is prevented from attending, and the requirement that the Tribunal align its procedures and conduct with the highest international standards of criminal justice indicates that it will not choose to. Thus a defendant prevented from attending trial who nonetheless designates defense counsel should not be convicted in his absence without an additional, affirmative waiver of his right to be present. Second, and alternatively, if the Tribunal treats the counsel's representation as an "appearance" by the defendant under Rule 104, Article 22 no longer applies, including its requirement that trials in absentia be held in certain circumstances. Using this approach, the judges would have full discretion to suspend further proceedings in the interests of justice until the restrictions on the defendant's ability to attend trial are lifted. ${ }^{197}$ Either way, the situation should never arise in which a defendant who has designated counsel but is prevented from attending trial is nevertheless convicted in his absence and would be barred under Article 22(3) from receiving a retrial.

Even if this situation were to arise, however, nothing in Article 22(3) appears to limit retrials to the specified conditions. Article 22(3) is structured so as to require access to retrial in particular situations, without specifying when retrial would be impermissible. If a situation presents itself where the STL judges believe it is in the interests of justice to allow a retrial, nothing in Article 22 would prevent them from ordering one, regardless of whether the situation falls within the scope of Article 22(3). ${ }^{198}$

More likely are the scenarios where a defendant who is fully aware of the trial chooses to sit it out and then seek a retrial if he is convicted. Under international jurisprudence, no retrial would be necessary because the defendant would have implicitly waived his right to attend. But the STL Statute relies not on waiver to deter-

197. See discussion of Rule 104 supra Part V.A.4.

198. Cf. Rules of Procedure and Evidence, supra note 23, rs. 190-91 (outlining procedure for review of judgments based on new evidence). If retrial were required in the interests of justice but the given circumstances did not fall under the scope of Article 22(3) or other Rules, the judges could invoke the inherent power of the Tribunal in ordering a retrial. See discussion of the Tribunal's inherent jurisdiction supra Part V.A.3. 
mine when retrial must be provided, but on the designation of counsel: as written, Article 22(3) would even require retrial for a defendant who expressly and in writing waived his right to attend trial but then did not designate his counsel. ${ }^{199}$ While the Tribunal could avoid this particular situation by requiring a defendant's written waiver to include a designation of counsel in order to be effective, ${ }^{200}$ there is no easy solution for the likelihood that a defendant will simply wait out the first trial and then request a retrial if he does not like the outcome. ${ }^{201}$

As an outcome that is over-protective of defendant's rights, there is no fundamental problem with this result. The excessiveness of it may simply be the cost of the Tribunal choosing to proceed in the absence of the accused, which may factor into the judges' calculation of the wisdom of pursuing a trial in absentia. But even if the guarantee of retrial is overbroad, it still has a concrete benefit: for an accused to exercise the right to retrial, he must first physically submit to the jurisdiction of the Tribunal. ${ }^{202}$ Thus, while the Tribunal may be forced to conduct anew a lengthy and expensive trial, ${ }^{203}$ it would gain in return the ability to execute the final judgment.

Finally, commentators have correctly noted the difficulty of protecting this right to retrial if the Tribunal has in the meantime closed its doors, it being an ad hoc court with a limited life span. ${ }^{204}$ The right to retrial is an important safeguard for the defendant's rights and an integral part of the justification for allowing trials in absentia in the first place. Yet the Statute and Rules do not appear to contemplate the possibility that a defendant may seek a retrial

199. See Gaeta, supra note 6, at 1170-71. While Professor Gaeta argues the Tribunal should not allow retrial in this instance, she does not explain how the judges could fairly circumscribe the scope of Article 22(3) as written.

200. For example, if the judges can be expected to infer that the express waiver in Article 22(1)(a) must be "unequivocal," see Part V.A.1 supra, they might in turn interpret "unequivocal" as including the designation of counsel, or the acceptance of counsel to be appointed by the Tribunal with the express understanding that such acceptance is equivalent to having "designated" counsel under Article 22(3).

201. See Gaeta, supra note 6, at 1171 (arguing the STL should not provide a retrial if the accused chose not to attend the first trial); Jordash \& Parker, supra note 6, at 499 (arguing that Article 22(3) creates a risk for abuse); Schabas, supra note 1, at 379 (suggesting Article 22(3) is overbroad).

202. Statute, supra note 2, art. 22(3) (providing for "the right to be retried in his or her presence before the Special Tribunal") (emphasis added).

203. But see Rules of Procedure and Evidence, supra note 23, r. 108 (allowing part of the in absentia proceedings to be used in retrial upon the defendant's consent).

204. See Gaeta, supra note 6, at 1172-73; Jenks, supra note 6, at 62; Jordash \& Parker, supra note 6, at 498; Schabas, supra note 1, at 379. 
long after the STL's mandate has expired. Professor Gaeta argues that Article 22(3) does not necessarily require retrial before the STL, ${ }^{205}$ but as Professor Schabas points out, such an approach is hard to square with Article 22(3)'s reference to "the right to be retried in [the defendant's] presence before the Special Tribunal." Alternatively, Professor Gaeta notes that because a conviction in absentia is not a final judgment, the non bis in idem bar of Article 5 would not apply, and the defendant could seek retrial before the Lebanese courts. ${ }^{207}$ This is a more promising approach.

Still, the Statute is far from clear on this matter, leading Professor Schabas to speculate that the STL "may have to remain in existence indefinitely if it ever convicts a defendant in absentia, so as to ensure the possible exercise of the right set out in Article 22(3)."208 The Trial Chamber would be well-advised to clarify its understanding of the relationship between Article 5 and Article 22(3) through amendments to the Rules or in any judgment of conviction it issues in the absence of the accused. Alternatively, it may be possible to add the STL's mandate to the Residual Mechanism established by the U.N. Security Council to continue the work of the ICTY and ICTR following their closure as independent institutions, ${ }^{209}$ or to establish a separate Residual Mechanism modeled after that of the ad hoc tribunals.

\section{Should the STL Conduct Trials in Absentia?}

While application of Article 22 will not necessarily run counter to international human rights jurisprudence, particularly if it is interpreted as suggested here, it is still a separate question whether a trial in absentia would be in the best interests of the Tribunaland the project of international criminal justice as a whole. Without a doubt, the STL judges will be well aware of the philosophical and practical costs of proceeding in the absence of a defendant.

205. Gaeta, supra note 6, at 1173 .

206. Schabas, supra note 1, at 379,379 n.187.

207. Gaeta, supra note 6 , at 1173 . Article 5 provides in part, "[n]o person shall be tried before a national court of Lebanon for acts for which he or she has already been tried by the Special Tribunal.” Statute, supra note 2, art. 5(1). But see Jordash \& Parker, supra note 6 , at 498 (arguing that Article 5's prohibition on trials before Lebanese courts when the accused has "already been tried" before the STL covers all trials before the STL, whether a final judgment has been issued or not).

208. Schabas, supra note 1 , at 379 .

209. See S.C. Res. 1966, U.N. Doc. S/RES/1966 (Dec. 22, 2010). The non bis in idem bar of Article 5 only extends to retrial before Lebanese courts, so this approach would not necessarily require amendment to the STL's Statute. 
Most problematically, the absence of the defendant will severely hamper the ability of counsel to mount a proper defense, thus undermining the truth-seeking function of the trial. ${ }^{210}$ As the ICTY Appeals Chamber has explained, in complex cases like those tried before the international criminal tribunals, "it would prove extremely difficult or even impossible for an international criminal court to determine the innocence or guilt of [an] accused" in his absence. ${ }^{211}$ Indeed, this is a major reason why some national courts have eschewed trials in absentia, as the term is applied here. ${ }^{212}$ In the case of the STL, the work of the defense counsel would be particularly challenging in the absence of an accused. Judging by the experiences of the ICTY and ICTR, combined with the length and size of the investigation undertaken first by the UNIIIC and then by the STL's prosecutor, any ensuing case will likely be extremely complex and may be based largely on technical or circumstantial evidence, ${ }^{213}$ the validity of which will be very difficult to challenge if counsel lacks access to the defendant's knowledge and contacts. This difficulty will be compounded if the STL judges allow the use of procedures that further circumscribe defense counsel's access to information, such as Rules permitting, in certain circumstances, the submission of anonymous witness statements ${ }^{214}$; the use of prior witness statements that have not been subject to cross-examination ${ }^{215}$; or the substitution of similar or redacted evidence in lieu of evidence that might jeopardize ongoing investigations, the safety of witnesses, or state security interests. ${ }^{216}$ Without the defendant's input, defense counsel will be hard-pressed to piece together such a convoluted jigsaw puzzle, with so many missing pieces.

Further, trials in absentia at the STL will be haunted by the practical costs of retrying the case later, if required to remedy a breach of the defendant's rights or as otherwise mandated by Article 22(3).

210. Wayne Jordash and Tim Parker argue this point very persuasively. See Jordash \& Parker, supra note 6, at 501-06; see also Pons, supra note 6, at 1319.

211. Prosecutor v. Blaškic, Case No. IT-95-14, Judgment on the Request of the Republic of Croatia for Review of the Decision of Trial Chamber II of 18 July 1997, I 59 (Int'l Crim. Tribunal for the Former Yugoslavia Oct. 29, 1997).

212. See, e.g., Crosby v. United States, 506 U.S. 255, 259, 261 (1993); CASSESE, supra note 63, at 390 n. 27 (quoting Claus Roxin to the effect that German courts require the presence of the criminal defendant to ensure proper adjudication).

213. See Prosecutor v. Ayyash et al., Case No. STL-11-01/I, Indictment, II 3 (June 10, 2011) (explaining that the indictment is based largely on circumstantial evidence).

214. See Rules of Procedure and Evidence, supra note 23, rs. 93, 159.

215. See id. rs. $155,158$.

216. Id. rs. 116-18. 
The ICTY judges rejected the idea that trials in absentia could improve the court's efficiency; besides expressing doubts about the fairness of such proceedings, ${ }^{217}$ they assumed that defendants tried in absentia would necessarily need to be retried once arrested, thereby increasing the workload of the tribunal.218 Based on the experience of the other international criminal tribunals, retrying just one case would cripple the limited resources of the STL, and the time required to retry even a single case would be measured in years, not months. These costs would be all the greater given that the present indictment is built primarily on technical and circumstantial evidence.

Finally, as critics have pointed out, proceeding with trials in absentia could also simply look bad. ${ }^{219}$ Given that the Tribunal's mission is in part to be seen to do justice, this is a real cost that should be borne in mind when deciding the advisability of conducting trials in absentia.

There should generally be, then, a strong presumption against conducting a trial in absentia. Nonetheless, if all efforts at securing the defendant's presence have failed, there may be some real benefits to a trial in absentia. At some point, the value of preventing a fugitive from obstructing justice, particularly when the crime at issue has harmed the very fabric of society, may take precedence. And even if a conviction in absentia will never be, legally or morally, a final judgment, there is nonetheless a benefit to building the factual record, even if potentially one-sided, for the benefit of future generations. $^{220}$ Indeed, this benefit-to ensure at least some

217. See U.N. Secretary-General, Comments on the Report of the Expert Group to Conduct a Review of the Effective Operation and Functioning of the International Tribunal for the Former Yugoslavia and the International Criminal Tribunal for Rwanda, I 10, U.N. Doc. A/54/850 (Apr. 27, 2000) ("Trials without the accused present are inherently unsatisfactory. They represent a 'second-best' system of justice that would diminish the standing of the ICTY and would downgrade the seriousness of the crimes, and substantially lessen the impact of international criminal justice."); see also Daryl A. Mundis, Improving the Operation and Functioning of the International Criminal Tribunals, 94 AM. J. INT'L L. 759, 762 (2000) (agreeing with the ICTY judges that trials in absentia "run counter to the norms of the emerging system of international criminal procedure" and would create more problems than they would solve).

218. See U.N. Secretary-General Letter dated Sept. 7, 2000 from the Secretary-General addressed to President of the General Assembly and the President of the Security Council, I 83, U.N. Doc. A/55/382-S/2000/865 (Sept. 14, 2000). (cited by Mundis, supra note 217, at 762 n.24).

219. See Jenks, supra note 6, at 97; see also Pons, supra note 6, at 1320 (explaining that international criminal trials in absentia could lead to a loss of credibility for the court and disappointment for the victims).

220. Cf. Pons, supra note 6, at 1320-21 (arguing the potential benefits of holding a trial in absentia as a last resort). 
points of stability in the historical record, while the evidence was still available-formed part of the ICTY's and ICTR's motivation in instituting the Rule 61 and Rule 71 bis procedures. Thus trials in absentia can provide at least partial justice from a societal perspective, even if they fall short of full vindication and closure for victims.

It is unclear, however, how much pure discretion the STL judges will have in weighing these competing interests given the strong wording of Article 22 that the STL "shall" conduct trials in absentia in certain circumstances. Such language signals the overall intent of those who wrote and adopted the Statute that the STL should use trials in absentia when the accused purposefully obstructs justice by refusing to participate, regardless of efficiency concerns or other practical considerations.

To preserve discretion in weighing these competing interests then, the judges should apply Article 22 narrowly and pragmatically. There is less concern in this respect for an absent defendant who expressly waives in writing his right to attend trial, ${ }^{221}$ but more concern in cases of implicit waiver: a defendant who refuses to surrender where no state will arrest him, or a defendant who absconds or cannot be found. Before proceeding in absentia, the judges should require clear evidence showing, inter alia, that the Tribunal has taken all reasonable steps to notify and secure the appearance of the accused ${ }^{222}$; that there is no potential for a state to arrest the accused within "a reasonable time"223; and that the accused has full knowledge of the charges and the pending trial. ${ }^{224}$ The benefits of interpreting and applying these conditions strictly include increasing the likelihood that the defendant's rights are protected-as well as furthering the public perception that this is the case-and ensuring that there is indeed no alternative to proceeding in absentia. Further, the judges should be prepared to conclude under Article 22(2) (a), when necessary, that the missing defendant can-

221. If the judges require the explicit waiver under Article 22(1) (a) to be informed, voluntary, and unequivocal and to include the designation of counsel, then there will be no basis for a retrial (obviating efficiency concerns) and very little room for criticism that the accused's rights are being violated (reducing concerns over perception). Counsel will also likely be in communication with the defendant in such circumstances, reducing the difficulties counsel face in representing absent accused. The Tribunal should nonetheless encourage the defendant in this scenario to participate in the trial as much as possible by communicating with his counsel and appearing via video-link, thereby furthering the truthseeking function of the Tribunal.

222. See Statute, supra note 2, art. 22(1)(c).

223. See Rules of Procedure and Evidence, supra note 23, r. 106(A)(ii).

224. See Statute, supra note 2, art. 22(2)(a). 
not be presumed to have received adequate information about the trial, despite the best efforts of the Tribunal's staff and relevant states.

Finally, the Tribunal must ensure that any defense counsel representing absent defendants receive adequate time and resources to undertake what will be a very challenging investigation, and that all procedural determinations, such as those related to evidentiary matters, are made with a particularly strong presumption towards protecting the rights and interests of the absent defendant.

\section{Conclusion}

As the STL moves forward with its first confirmed indictment, its work could well be delayed and frustrated by the political reality of Lebanon and the region. In the end, a trial in absentia may be the only option to achieve even partial justice for terrorist crimes that severely disrupted Lebanese society. Under the framework imposed by the STL's Statute, as interpreted according to the Tribunal's own jurisprudence, such a trial will be in accordance with universal human rights and the highest international standards of criminal justice. While acceptable and perhaps necessary, however, trials in absentia will never be an ideal outcome and should only be used if all other options fail-and, if the defendant's rights may not be fully guaranteed, perhaps not even then. 